\title{
From long-lived batholith construction to giant porphyry copper deposit formation: petrological and zircon chemical evolution of the Quellaveco District, Southern Peru
}

\author{
Chetan L. Nathwani ${ }^{1,2} \cdot$ Adam T. Simmons $^{3} \cdot$ Simon J. E. Large ${ }^{1}$ Jamie J. Wilkinson ${ }^{1,2}$ - Yannick Buret ${ }^{1}$. \\ Christian Ihlenfeld ${ }^{3}$
}

Received: 12 August 2020 / Accepted: 17 December 2020 / Published online: 28 January 2021

(c) The Author(s) 2021

\begin{abstract}
Porphyry $\mathrm{Cu}$ ore deposits are a rare product of arc magmatism that often form spatiotemporal clusters in magmatic arcs. The petrogenetic evolution of igneous rocks that cover the temporal window prior to and during porphyry $\mathrm{Cu}$ deposit formation may provide critical insights into magmatic processes that are key in generating these systems. This study documents the magmatic evolution of the Palaeocene-Eocene Yarabamba Batholith, Southern Peru, that was incrementally assembled between $\sim 67$ and $\sim 99 \mathrm{Ma}$ and hosts three, nearly contemporaneous, giant porphyry $\mathrm{Cu}-\mathrm{Mo}$ deposits that formed at 57-54 Ma (Quellaveco, Toquepala and Cuajone). Whole-rock geochemistry, U-Pb geochronology and zircon trace element chemistry are reported from Yarabamba rocks that span the duration of plutonic activity, and from six porphyry intrusions at Quellaveco that bracket mineralisation. A change in whole-rock chemistry in Yarabamba intrusive rocks to high $\mathrm{Sr} / \mathrm{Y}, \mathrm{high} \mathrm{La} / \mathrm{Yb}$ and high $\mathrm{Eu} / \mathrm{Eu}^{*}$ is observed at $\sim 60 \mathrm{Ma}$ which is broadly coincident with a change in vector of the converging Nazca plate and the onset of regional compression and crustal thickening during the first stage of the Incaic orogeny. The geochemical changes are interpreted to reflect a deepening of the locus of lower crustal magma evolution in which amphibole \pm garnet are stabilised as early and abundant fractionating phases and plagioclase is suppressed. Zircons in these rocks show a marked change towards higher $\mathrm{Eu} / \mathrm{Eu}^{*}(>0.3)$ and lower Ti $(<9 \mathrm{ppm})$ compositions after $\sim 60 \mathrm{Ma}$. Numerical modelling of melt Eu systematics and zircon-melt partitioning indicates that the time series of zircon $\mathrm{Eu} / \mathrm{Eu}^{*}$ in these rocks can be explained by a transition from shallower, plagioclase-dominated fractionation to high-pressure amphibole-dominated fractionation at deep crustal levels from $\sim 60 \mathrm{Ma}$. Our modelling suggests that any redox effects on zircon $\mathrm{Eu} / \mathrm{Eu}^{*}$ are subordinate compared to changes in melt composition controlled by the fractionating mineral assemblage. We suggest that growth and intermittent recharge of the lower crustal magma reservoir from $\sim 60$ Ma produced a significant volume of hydrous and metallogenically fertile residual melt which ascended to the upper crust and eventually generated the three giant porphyry $\mathrm{Cu}-\mathrm{Mo}$ deposits at Quellaveco, Toquepala and Cuajone from $~ 57 \mathrm{Ma}$. Our study highlights the importance of high-pressure magma differentiation fostered by strongly compressive tectonic regimes in generating world-class porphyry $\mathrm{Cu}$ deposits.
\end{abstract}

Keywords Porphyry copper deposit $\cdot$ Magma fertility $\cdot$ Zircon petrochronology $\cdot$ Eu anomaly $\cdot$ Deep crustal evolution · Petrogenetic modelling

Communicated by Othmar Müntener.

Supplementary Information The online version contains supplementary material available at https://doi.org/10.1007/s0041 0-020-01766-1.

Chetan L. Nathwani

chetan.nathwani14@imperial.ac.uk

1 London Centre for Ore Deposits and Exploration (LODE), Department of Earth Sciences, Natural History Museum, Cromwell Road, South Kensington, London SW7 5BD, UK
2 Department of Earth Science and Engineering, Imperial College London, Exhibition Road, South Kensington Campus, London SW7 2AZ, UK

3 Anglo American Plc, 20 Carlton House Terrace, London SW1Y 5AN, UK 


\section{Introduction}

Porphyry $\mathrm{Cu}$ ore deposits are the products of large, longlived, trans-crustal arc magma systems that release and focus metal-charged fluids during the intrusion of porphyritic stocks and dykes (Dilles 1987; Seedorf et al. 2005; Sillitoe 2010). The occurrence of these economically valuable deposits is typically restricted to narrow arc segments-in lineaments or clusters that are formed during specific temporal windows within arc evolution (Sillitoe 2010). The formation of porphyry $\mathrm{Cu}$ deposits has been linked to distinctive changes in the trace element chemistry of igneous rocks that crystallised immediately prior to ore genesis, including increased whole-rock $\mathrm{Sr} / \mathrm{Y}(>50)$, $\mathrm{La} / \mathrm{Yb}(>20)$ and Eu/Eu* (>0.3) (Lang and Titley 1998; Rohrlach and Loucks 2005; Richards and Kerrich 2007; Richards 2011; Richards et al. 2012; Loucks 2014).

The origin of the characteristic trace element signatures of magmas parental to porphyry ore deposits has been attributed to a protracted evolution in the lower crust (e.g.,Rohrlach and Loucks 2005; Chiaradia et al. 2009; Wilkinson 2013; Chelle-Michou et al. 2015), linked to an inhibition of magma ascent. This is thought to be related to perturbations in regional geodynamics that generate intense but transient compression and crustal thickening (Cooke et al. 2005; Rosenbaum et al. 2005). Longterm evolution in the lower crust causes mantle-derived magmas to undergo extensive fractional crystallisation and assimilation of pre-existing crust, thereby attaining diverse, evolved compositions (DePaolo 1981; Hildreth and Moorbath 1988; Lang and Titley 1998; Annen et al. 2006). Here, high pressure ( $>0.7 \mathrm{GPa}$ ) combined with high melt water contents ( $>5 \mathrm{wt} . \%$ ) cause a change in the fractionating mineral assemblage and its crystallisation sequence (Loucks 2014; Müntener and Ulmer 2018). This increased water content and pressure promotes the stability of amphibole \pm garnet (in which Y and MREE/ HREEs are compatible) as early and abundant crystallising and fractionating phases, whereas crystallisation of plagioclase (in which $\mathrm{Sr}$ and Eu are compatible) is suppressed (Müntener et al. 2001; Alonso-Perez et al. 2008; Melekhova et al. 2015).

The reason for the association of giant porphyry $\mathrm{Cu}$ ore deposits with high $\mathrm{Sr} / \mathrm{Y}$ and high $\mathrm{La} / \mathrm{Yb}$ ratios in coeval igneous whole rocks remains equivocal. However, extensive evolution of magmas in the lower crust is thought to enrich them in water (e.g., Melekhova et al. 2015), in part because water is more soluble in melts at high pressure (e.g., Newman and Lowenstern 2002). Modelling suggests that following ascent to the shallow crust, such hydrous ( $>5$ wt. $\% \mathrm{H}_{2} \mathrm{O}$ ) magmas are predisposed to exsolve enough metalliferous fluid during decompression and crystallisation to generate and maintain large magmatichydrothermal ore systems (Chiaradia and Carrichi 2017). Furthermore, a higher melt $\mathrm{fO}_{2}$ obtained during lower crustal fractionation (Lee et al. 2005; Tang et al. 2018; Ulmer et al. 2018) has been suggested to increase sulphur and metal solubility, resulting in delayed sulphide saturation that could otherwise lead to loss of chalcophile elements from the melt (Jenner et al. 2010; Lee et al. 2012). Recent studies have shown that sulphide saturation in arc magmas is inevitable even under oxidised $(>\mathrm{NNO}+2)$ and lower crustal conditions (Matjuschkin et al. 2016; Du and Audétat 2020), indicating that exceptionally high melt $\mathrm{fO}_{2}$ may not be fundamental in forming porphyry $\mathrm{Cu}$ deposits.

Further studies of the petrogenesis of magmas parental to porphyry $\mathrm{Cu}$ deposits have focused on zircon trace element chemistry, because zircon is resistant to re-equilibration during the extensive hydrothermal alteration associated with these systems. A key observation has been the presence of higher $\mathrm{Eu} / \mathrm{Eu}^{*}$ in zircons from igneous rocks spatiotemporally associated with porphyry $\mathrm{Cu}$ systems, compared to older intrusions not associated with mineralisation in the same igneous complex. This has been used to argue for an elevated oxidation state $\left(f \mathrm{O}_{2}\right)$ of magmas parental to porphyry $\mathrm{Cu}$ deposits (e.g.,Ballard et al. 2002; Liang et al. 2006; Dilles et al. 2015), because $\mathrm{Eu}$ is more compatible in zircon under oxidised conditions, where $\mathrm{Eu}^{3+}$ is dominant over $\mathrm{Eu}^{2+}$ (Burnham and Berry 2012). However, this remains ambiguous, since zircon $\mathrm{Eu} / \mathrm{Eu}^{*}$ is sensitive to several other parameters such as the co-crystallising mineral assemblage, melt composition and temperature (Burnham et al. 2015; Loader et al. 2017).

In this study, we aim to better understand the magmatic processes that determine the formation of giant porphyry $\mathrm{Cu}$ ore deposits by tracking the long-lived magmatic evolution of the Yarabamba Batholith and its associated porphyry $\mathrm{Cu}-\mathrm{Mo}$ deposits, Southern Peru. The compositional evolution of the batholith and the igneous rocks associated with porphyry mineralisation provide constraints on the tempo and nature of the magmatic evolution that preceded and ultimately generated three giant porphyry $\mathrm{Cu}-\mathrm{Mo}$ deposits in the district: Quellaveco, Cuajone and Toquepala. Our approach integrates whole-rock chemistry with zircon $\mathrm{U}-\mathrm{Pb}$ geochronology and trace-element chemistry to show that both whole-rock and zircon data record a transition in magma chemistry at $\sim 60 \mathrm{Ma}$ that reflects a deepening of the locus of crustal magma evolution, prior to district-wide mineralisation.

\section{Regional geology}

The Yarabamba Batholith is part of the Coastal Batholith which extends $1100 \mathrm{~km}$ along much of the length of the Peruvian Andes (Myers 1975; Cobbing and Pitcher 1972; 
Clark et al. 1990). The Yarabamba Batholith intrudes the Toquepala Group, which predominantly comprises intermediate-felsic volcanics of mid to late Cretaceous age (91-69 Ma; Simmons 2013). The Toquepala volcanics formed during a period of major tectonic perturbation that led to the closure of back-arc basins, amalgamation of arc terranes and deformation of sedimentary and volcanic rocks (Mpodozis and Ramos 1989). Segmentation of the arc occurred due to lateral heterogeneity in the subducting Nazca plate, creating changes in the angle of subduction and, therefore, the style and intensity of compression and volcanism (Ramos 2009; Capitanio et al. 2011; Hu et al. 2016). The youngest rocks of the Toquepala Group ( $\sim 67 \mathrm{Ma})$, typically found at high altitudes between Quellaveco and Toquepala, overlap in age with the oldest intrusive activity of the Yarabamba Batholith (67-69 Ma) (Simmons 2013).
The Yarabamba Batholith is a composite plutonic complex (Fig. 1) assembled by the emplacement of discrete batches of dioritic-granodioritic magma between $\sim 67$ and $59 \mathrm{Ma}$ (Mukasa 1986; Demouy et al. 2012; Simmons et al. 2013) during a period of relatively oblique and low rates of convergence of the Nazca plate (Pardo-Casas and Molnar 1987; Mpdozis and Cornejo 2012). Lead isotopic data indicate that these magmas experienced little interaction with the Precambrian granulitic basement (Barreiro and Clark 1984). The final phase of this magmatic activity was the emplacement of three, near contemporaneous, major porphyry $\mathrm{Cu}-\mathrm{Mo}$ systems in the Eocene (Quellaveco 58.4-54.3 Ma; Toquepala 57.0-54.0 Ma; and Cuajone 56.5-53.0 Ma; Sillitoe and Mortensen 2010; Simmons et al. 2013). The emplacement of these porphyry $\mathrm{Cu}-$ Mo systems has been associated with high rates of tectonic compression (e.g., Benavides-Cáceres 1999). Post-mineralisation,

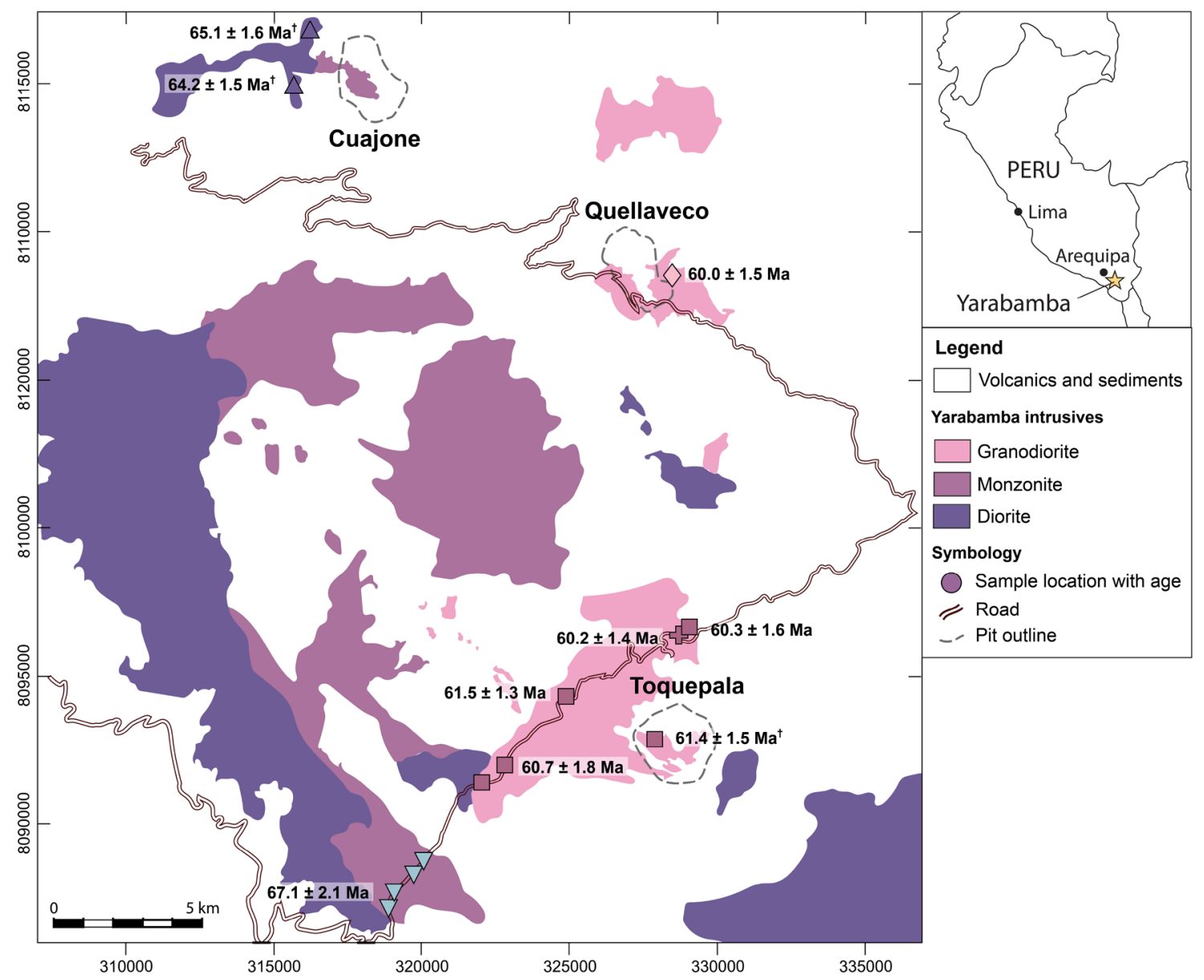

Fig. 1 Regional geological map of the Yarabamba Batholith and giant porphyry $\mathrm{Cu}-\mathrm{Mo}$ deposits. Colourless areas are Palaeocene volcanics that pre-date the batholith, younger Miocene volcaniclastic and sedimentary rocks, and Plio-Pleistocene sediments. The Quellaveco deposit is hosted within the Yarabamba Batholith. Shapes show the location of regional samples of the Yarabamba Batholith with ages shown for samples that were dated, all other samples were collected from drill core at Quellaveco. Symbol shapes and colours are those used in subsequent figures (see key Fig. 2). Simplified after Bellido (1979). Inset map of Peru shows the location of the study area (star). $\dagger$ Ages published in Simmons et al. (2013) and whole-rock geochemical data for these samples are reported herein 
the region underwent up to $40^{\circ}$ counter-clockwise rotation during later crustal shortening and oroclinal bending during the Eocene-Oligocene (Arriagada et al. 2008).

\section{The Quellaveco porphyry Cu-Mo deposit}

The Quellaveco porphyry Cu-Mo deposit (Fig. 2) is one of the world's largest unexploited copper resources with ore reserves of 1.3 billion tonnes at $0.57 \% \mathrm{Cu}$ (Anglo American, Annual Report 2019). At least six intrusive porphyry phases have been identified at the deposit which form stock and dyke complexes (Fig. 2) emplaced over 4 Myr (Sillitoe and Mortensen 2010). The Quellaveco porphyries
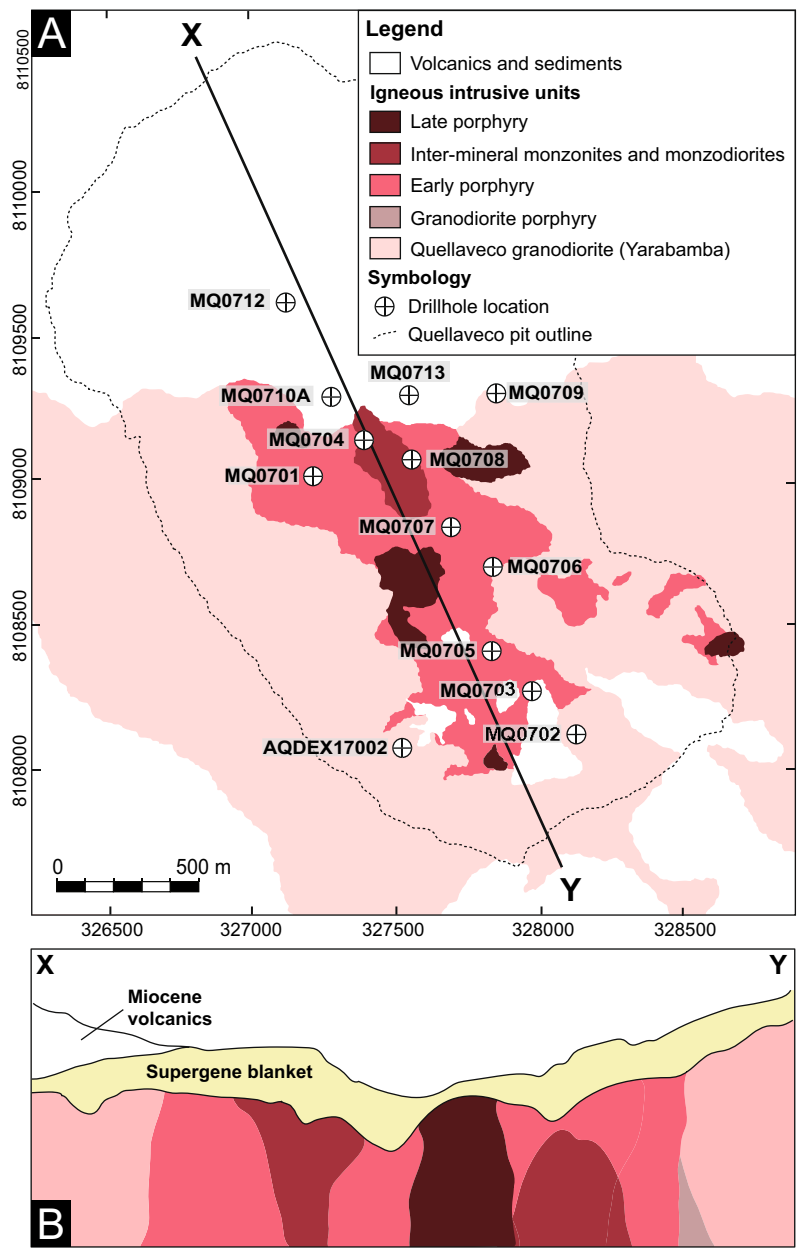

Fig. 2 a Simplified geological map of the Quellaveco porphyry $\mathrm{Cu}-$ Mo deposit and the proposed open-pit plan with positions of sampled drill-holes marked. After Simmons (2013). Depths and intervals sampled from each drill core for specific samples are provided in Supplementary Material 2. Approximate line of section shown for Fig. 2b. b Schematic NNW-SSE cross-section of the Quellaveco intrusive complex illustrating cross-cutting relationships of the porphyry intrusive phases are hosted within a pluton that is a late member of the Yarabamba Batholith (LA-ICP-MS U-Pb zircon date of $59.46 \pm 0.24 \mathrm{Ma}$; Sillitoe and Mortensen 2010), referred to as the Quellaveco Granodiorite. This host rock is an equigranular granodiorite, with alteration grading from weak propylitic (chlorite + epidote) at the periphery of the system, to strong potassic (biotite + K-feldspar) at the core.

Following the lithological classification of Simmons (2013), drill core observations of cross-cutting relationships allow the relative chronology of the porphyry phases to be reconstructed, especially where intrusive contacts truncate vein generations and alteration assemblages (Fig. 3). All units at Quellaveco exhibit a porphyritic texture dominated by feldspar phenocrysts; the emplacement of each of these was accompanied by separate phases of sulphide-mineralisation and hydrothermal alteration that generally decrease in intensity through the lifespan of the system (Simmons 2013). Each phase of hydrothermal alteration consisted of an initial potassic alteration that replaced mafic minerals and felspars with secondary biotite and K-feldspar, respectively. This was followed by texturally destructive phyllic alteration associated with quartz, sericite and pyrite deposition.

The earliest porphyry unit observed at Quellaveco is termed the "Granodiorite Porphyry". Previously only found as xenoliths within the later porphyry units, it has been intersected at depth in recent drilling. The Granodiorite Porphyry is characterised by a more equigranular texture compared to the other porphyry units (euhedral $>2 \mathrm{~mm}$ amphibole phenocrysts) and exhibits intense potassic alteration and extensive chalcopyrite mineralisation. Cross-cutting relationships indicate that its emplacement was associated with weak sulphide-mineralisation and preceded the bulk of $\mathrm{Cu}$ mineralisation at Quellaveco (Simmons 2013). The second unit emplaced at Quellaveco, the "Early Porphyry", forms a stock $\sim 1 \times 2 \mathrm{~km}$ in surface area and hosts most of the $\mathrm{Cu}$-ore in the deposit. This unit is granodioritic and is characterised by plagioclase (25\%), K-feldspar (15\%), euhedral quartz $(15 \%)$ and biotite phenocrysts (10\%). The Early Porphyry is cut by a sequence of porphyry dykes and a stock complex in the centre of the deposit (Fig. 2):

(1) The first inter-mineral porphyry, the Monzonite Porphyry, occurs as a series of dykes and is characterised by its high phenocryst abundance (60\%) including feldspars (50\%), anhedral quartz (10\%) and biotite (5\%).

(2) A second inter-mineral porphyry phase, the Monzodiorite Porphyry, forms metre-scale dykes characterised by a distinctively low phenocryst abundance $(25 \%)$ of plagioclase (20\%), K-feldspar (2\%), quartz (5\%), biotite (3\%), amphibole (2\%) and a fine-grained, relatively mafic, groundmass. 
Fig. 3 Drill-core images of principal lithologies and crosscutting relationships from the Quellaveco porphyry $\mathrm{Cu}-\mathrm{Mo}$ deposit. a Contact between the Quellaveco Granodiorite host rock (gd) with an intermineral Monzonite Porphyry dyke, with truncated quartz-biotite vein. b Xenolith of Early Porphyry with abundant disseminated chalcopyrite mineralisation hosted by unmineralised, altered Monzodiorite Porphyry dyke. c Contact between highly altered intermineral Monzonite Porphyry (containing abundant quartz veins) and Late Porphyry, with contact cut by a quartz-sericite-pyrite vein. d Chilled contact of Late Porphyry and Monzodiorite Porphyry dyke
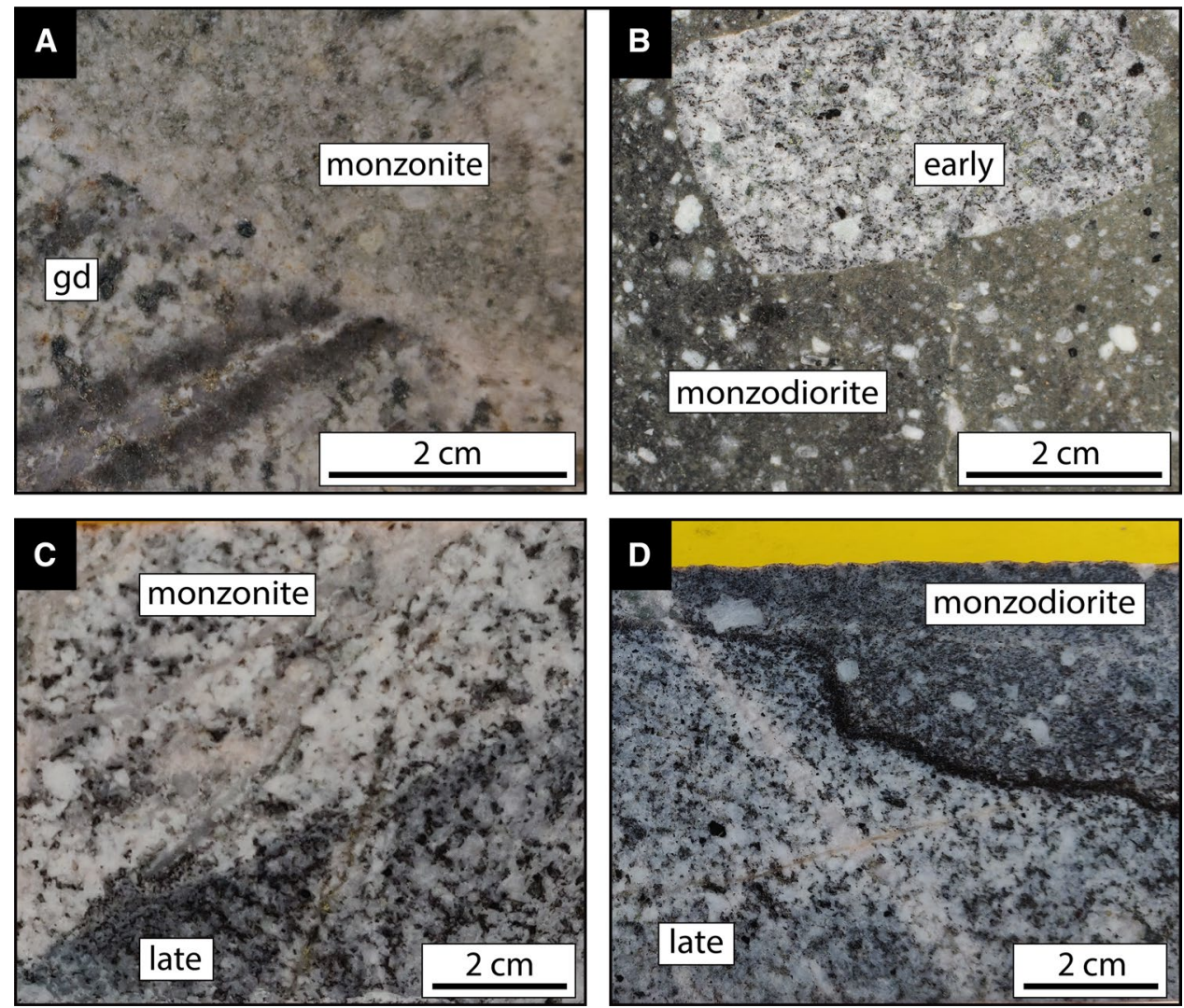

(3) The Late Porphyry intrusion, that post-dates most of the $\mathrm{Cu}$-mineralisation, contains plagioclase (40\%), K-feldspar $(10 \%)$, quartz (10\%), biotite $(8 \%)$ and euhedral hornblende $(2 \%)$ phenocrysts, and only displays weak phyllic alteration.

(4) The final igneous event at Quellaveco is represented by volumetrically minor dacite dykes that post-date the entirety of $\mathrm{Cu}$-mineralisation; these are fine-/mediumgrained and contain plagioclase (10\%), K-feldspar (5\%), subhedral quartz (15\%) and euhedral amphibole (2\%) phenocrysts.

\section{Methods}

\section{Sample selection}

To represent the time period of magmatic evolution prior to and during porphyry $\mathrm{Cu}$ ore deposit formation, samples were collected from Yarabamba intrusions in the district that predate mineralisation and from intrusions at the Quellaveco porphyry $\mathrm{Cu}-\mathrm{Mo}$ deposit. Thirteen samples of Yarabamba intrusive rock were collected from several outcrops found in the district (Figs. 1, 2) for whole-rock geochemical analysis, including the Yarabamba host rocks for each of the three major porphyry $\mathrm{Cu}-\mathrm{Mo}$ deposits: (1) six from a granodiorite intrusion that hosts and surrounds the Toquepala deposit, including one sample from the Toquepala open pit; (2) two from the diorite-monzonite intrusions that host, and crop out to the west of, the Cuajone deposit; (3) four from an extensive diorite-monzonite intrusion at the southern limit of the district; (4) one from the Quellaveco Granodiorite, sampled to the east of the Quellaveco deposit. Samples of least-altered Quellaveco porphyry intrusions $(n=51)$ and a further seven samples of the Quellaveco Granodiorite were collected from logged drill core at the Quellaveco deposit for whole-rock geochemical analysis.

From this sample-set, a representative sub-set of fifteen duplicate samples were chosen for zircon separation. Six samples from the Yarabamba intrusive suite were selected plus nine drill core samples from Quellaveco: one sample of mineralised host rock (Quellaveco Granodiorite), one sample of the earliest Granodiorite Porphyry, one sample of the Early Porphyry, two samples of inter-mineral Monzonite Porphyry, one sample of late inter-mineral Monzodiorite, two samples of the Late Porphyry and one sample of a postmineralisation dacite dyke.

\section{Whole-rock major and trace element analysis}

Crushing and whole-rock geochemical analysis were carried out at Bureau Veritas (Vancouver, Canada) and the codes for 
each package are provided below. Further details are available at http://acmelab.com/services/method-descriptions/. Samples were crushed to $\geq 70 \%$ passing $2 \mathrm{~mm}$, and a $250 \mathrm{~g}$ split of this material was then pulverised to $\geq 85 \%$ passing $75 \mu \mathrm{m}$. The remainder of the initial coarse product was used for mineral separation. Pulps were then dried at $105^{\circ} \mathrm{C}$ prior to analysis, with fractions taken from the pulp for different analytical procedures.

A $0.2 \mathrm{~g}$ aliquot of each sample was fused using lithium borate flux to make a glass bead. This was subsequently dissolved in $5 \%$ nitric acid. Major elements $\left(\mathrm{SiO}_{2}, \mathrm{Al}_{2} \mathrm{O}_{3}\right.$, $\mathrm{Fe}_{2} \mathrm{O}_{3}, \mathrm{MgO}, \mathrm{CaO}, \mathrm{Na}_{2} \mathrm{O}, \mathrm{K}_{2} \mathrm{O}, \mathrm{TiO}_{2}, \mathrm{P}_{2} \mathrm{O}_{5}, \mathrm{MnO}, \mathrm{Cr}_{2} \mathrm{O}_{5}$, $\mathrm{Ba}$ and $\mathrm{Sc}$ ) were determined by inductively-coupled plasma atomic emission spectrometry (ICP-AES) under procedure LF300. Refractory and rare earth elements were determined using the same solution using inductively-coupled plasma mass spectrometry (ICP-MS) under procedure LF100. Elements measured were Ba, Be, Ce, Co, Cs, Dy, Er, Eu, Ga, Gd, Hf, Ho, La, Lu, Nb, Nd, Pr, Rb, Sm, Sn, Sr, Ta, Tb, $\mathrm{Th}, \mathrm{Tm}, \mathrm{U}, \mathrm{V}, \mathrm{W}, \mathrm{Y}, \mathrm{Yb}$ and $\mathrm{Zr}$. Loss on ignition (procedure TG001) was determined by heating $1 \mathrm{~g}$ of sample to $1000{ }^{\circ} \mathrm{C}$ and measuring the mass difference. Carbon and sulphur (procedure TC000) were determined by combusting $0.1 \mathrm{~g}$ of sample using LECO (infrared absorption and thermal conductivity). Information on the standards analysed and the accuracy and precision of whole-rock analysis is available in Supplementary Material 2.

\section{Zircon geochronology and trace element analysis}

Coarse rejects for selected samples were sieved to $500 \mu \mathrm{m}$, panned for heavy mineral separates, and passed under a neodymium magnet to remove magnetic grains. Zircons from each heavy mineral separate were picked, mounted in epoxy and polished to expose crystal cores in preparation for microanalysis.

To characterise zircon textures, each population was imaged by scanning electron microscope-cathodoluminescence (SEM-CL) using a Zeiss EVO SEM located in the Imaging and Analysis Centre (IAC), Natural History Museum, London. The instrument was operated with a 3.0 $\mathrm{nA}$ beam current and $10 \mathrm{kV}$ accelerating voltage. Subsequent zircon trace element analysis was conducted in the LODE Laboratory, IAC, using an Agilent 7700x quadrupole ICP-MS coupled to an ESI New Wave Research NWR193 excimer laser. The laser was operated using a $5 \mathrm{~Hz}$ repetition rate, a fluence of $\sim 3.5 \mathrm{~J} \mathrm{~cm}^{-2}$ and a spot size of $30 \mu \mathrm{m}$. Spots were selected using SEM-CL images to allow targeting of individual crystal domains for intra-crystal, core-rim analyses. The following isotopes were analysed: ${ }^{27} \mathrm{Al},{ }^{28} \mathrm{Si}$, ${ }^{31} \mathrm{P},{ }^{43} \mathrm{Ca},{ }^{49} \mathrm{Ti},{ }^{51} \mathrm{~V},{ }^{57} \mathrm{Fe},{ }^{89} \mathrm{Y},{ }^{93} \mathrm{Nb},{ }^{137} \mathrm{Ba},{ }^{139} \mathrm{La},{ }^{140} \mathrm{Ce}$, ${ }^{141} \mathrm{Pr},{ }^{145} \mathrm{Nd},{ }^{147} \mathrm{Sm},{ }^{151} \mathrm{Eu},{ }^{157} \mathrm{Gd},{ }^{159} \mathrm{~Tb},{ }^{163} \mathrm{Dy},{ }^{165} \mathrm{Ho}$, ${ }^{167} \mathrm{Er},{ }^{169} \mathrm{Tm},{ }^{173} \mathrm{Yb},{ }^{175} \mathrm{Lu},{ }^{177} \mathrm{Hf},{ }^{181} \mathrm{Ta},{ }^{201} \mathrm{Hg},{ }^{204} \mathrm{~Pb},{ }^{206} \mathrm{~Pb}$,
${ }^{207} \mathrm{~Pb},{ }^{208} \mathrm{~Pb},{ }^{232} \mathrm{Th}$ and ${ }^{238} \mathrm{U}$. Dwell time for each element was $10 \mathrm{~ms}$ with the exception of ${ }^{49} \mathrm{Ti},{ }^{139} \mathrm{La},{ }^{141} \mathrm{Pr}$ and ${ }^{235} \mathrm{U}$ (20 ms); ${ }^{206} \mathrm{~Pb},{ }^{207} \mathrm{~Pb}$ and ${ }^{238} \mathrm{U}$ (30 ms); and ${ }^{27} \mathrm{Al},{ }^{43} \mathrm{Ca},{ }^{57} \mathrm{Fe}$ and ${ }^{91} \mathrm{Zr}$ (5 ms). NIST-610 was the primary reference material used for trace element quantification and NIST612 and zircon 91,500 were used to monitor accuracy and precision. A stoichiometric value for Si (15.3 wt.\%) was used as the internal standard. GJ-1 (ca. $601 \mathrm{Ma}$; Jackson et al. 2004) was used as the primary geochronology standard and Fish Canyon Tuff and zircon 91,500 were analysed between each set of unknowns to ensure consistency and accuracy in the $\mathrm{U}-\mathrm{Pb}$ ages obtained (Wiedenbeck et al. 2004; Wotzlaw et al. 2013). Data reduction was performed using Iolite v. 3.61 (Paton et al. 2011), where the ${ }^{206} \mathrm{~Pb} /{ }^{238} \mathrm{U}$ and ${ }^{207} \mathrm{~Pb} /{ }^{235} \mathrm{U}$ spectra were monitored for isotopic heterogeneity. Analyses that were found to be discordant or with anomalously high $\mathrm{Al}, \mathrm{P}, \mathrm{Ca}, \mathrm{Fe}$ and $\mathrm{La}$ (indicating the presence of mineral and melt inclusions) are not included in the reported data. Further information on the analytical methods, standards, typical analytical precision and limits of detection is available in Supplementary Material 2.

Three samples were dated by secondary ion mass spectrometry (SIMS) using the Sensitive High Resolution Ion Microprobe-Reverse Geometry facility (SHRIMP-RG) at Stanford University, in co-operation with the US Geological Survey. Zircons were sputtered with an $\mathrm{O}_{2}$ - primary ion beam varying from 4-5 nA with a spot diameter of $20-40 \mu \mathrm{m}$ and a depth of $1-2 \mu \mathrm{m}$. The acquisition routine began with the high mass normalizing species $\left({ }^{90} \mathrm{Zr}_{2}{ }^{16} \mathrm{O}^{+}\right)$, followed by ${ }^{204} \mathrm{~Pb}^{+}$, a background measured at 0.050 mass units above ${ }^{204} \mathrm{~Pb}^{+},{ }^{206} \mathrm{~Pb}^{+},{ }^{207} \mathrm{~Pb}^{+},{ }^{208} \mathrm{~Pb}^{+},{ }^{238} \mathrm{U}^{+},{ }^{232} \mathrm{Th}^{16} \mathrm{O}^{+}$ and ${ }^{238} \mathrm{U}^{16} \mathrm{O}^{+}$and ${ }^{232} \mathrm{Th}^{+}$. The obtained dates were standardised against the R33 zircon standard (419 Ma; Black et al. 2004). A full description of the analytical technique and data reduction is provided in Simmons et al. (2013) and in Supplementary Material 1.

\section{Results}

\section{$\mathrm{U}-\mathrm{Pb}$ geochronology}

A total of 762 zircon analyses are reported from twelve samples with both $\mathrm{U}-\mathrm{Pb}$ dates and trace element chemistry, acquired using LA-ICP-MS (Supplementary Material 2). A further 42 zircon analyses are reported with only $\mathrm{U}-\mathrm{Pb}$ dates, determined by the SHRIMP-RG method. For the individual samples, weighted mean dates were calculated for concordant ${ }^{206} \mathrm{~Pb} /{ }^{238} \mathrm{U}$ dates together with mean square weighted deviation (MSWD) values, which ranged from 0.21 to 5.31 (Fig. 4 and Table 1). One sample of Quellaveco Granodiorite yielded few concordant dates and a discordia date was calculated and reported instead of a weighted mean (Fig. 4 


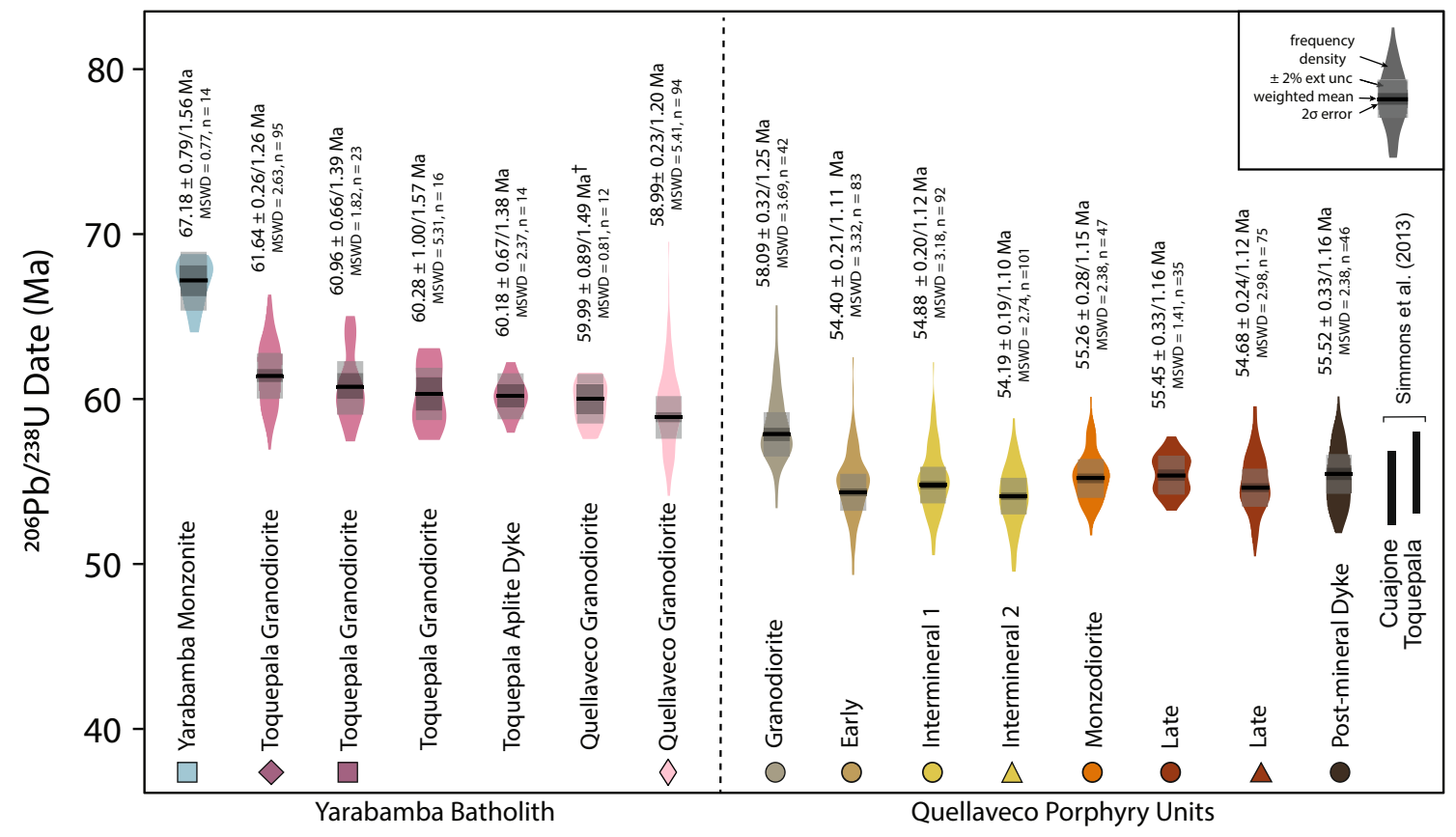

Fig. 4 Violin plot showing the density of ${ }^{206} \mathrm{~Pb} /{ }^{238} \mathrm{U}$ dates obtained for zircons from each rock. Horizontal lines indicate the weighted mean for each plot. Dark grey boxes show the $2 \sigma$ uncertainty and paler grey boxes show the propagated error for LA-ICP-MS ${ }^{206} \mathrm{~Pb} /{ }^{238} \mathrm{U}$ dates of $\pm 2 \%$. Annotated dates are given with two uncertainties: (1) the $2 \sigma$ uncertainty from mean square weighted deviation (MSWD) and (2) with propagated external uncertainty of 2\%. MSWD and number of analyses are also given. Samples are plotted left-toright according to age ranking for the Yarabamba rocks and plotted left-right according to cross-cutting relationships for the Quellaveco porphyry rocks. Symbols besides sample units show the symbology used in zircon trace-element plots; for the three samples with no symbol shown, these samples were dated using the SHRIMP-RG method and zircon trace elements are not reported here. Black vertical bars indicate the range of $\mathrm{U}-\mathrm{Pb}$ zircon $\mathrm{LA}-\mathrm{ICP}-\mathrm{MS}$ dates reported by Simmons et al. (2013) for the neighbouring Cuajone and Toquepala porphyry $\mathrm{Cu}$ systems. $†$ One Quellaveco Granodiorite sample yielded few concordant ages, so a discordia date was calculated and reported instead of a weighted mean
Table 1 Summary of zircon ${ }^{206} \mathrm{~Pb} /{ }^{238} \mathrm{U}$ geochronology data for Yarabamba intrusives and Quellaveco porphyry units

\begin{tabular}{|c|c|c|c|c|c|c|}
\hline Formation & Sample & $\begin{array}{l}\text { Weighted } \\
\text { Mean } \\
(\mathrm{Ma})\end{array}$ & $2 \sigma$ uncertainty & $\begin{array}{l}2 \sigma+2 \% \\
\text { external } \\
\text { uncertainty }\end{array}$ & $\mathrm{n}$ & MSWD \\
\hline Yarabamba Monzonite & QVC075 & 67.18 & 0.79 & 1.56 & 14 & 0.77 \\
\hline \multirow[t]{3}{*}{ Toquepala Granodiorite } & QVC083 & 61.64 & 0.26 & 1.26 & 95 & 2.63 \\
\hline & QVC082 & 60.96 & 0.66 & 1.39 & 23 & 1.82 \\
\hline & Qu380* & 60.28 & 1.00 & 1.57 & 16 & 5.31 \\
\hline Toquepala Aplite Dyke & Qu381* & 60.18 & 0.67 & 1.38 & 14 & 2.37 \\
\hline \multirow[t]{2}{*}{ Quellaveco Granodiorite } & $\mathrm{Qu} 008^{* \dagger}$ & 59.99 & 0.89 & 1.49 & 12 & 0.81 \\
\hline & QVC028 & 58.99 & 0.23 & 1.20 & 94 & 5.41 \\
\hline Granodiorite Porphyry & QVC091 & 58.09 & 0.32 & 1.25 & 42 & 3.69 \\
\hline Early Porphyry & QVC034 & 54.40 & 0.21 & 1.11 & 83 & 3.32 \\
\hline \multirow[t]{2}{*}{ Intermineral Monzonite Porphyry } & QVC060 & 54.88 & 0.20 & 1.12 & 92 & 3.18 \\
\hline & QVC024 & 54.19 & 0.19 & 1.10 & 101 & 2.74 \\
\hline Monzodiorite Porphyry & QVC061 & 55.26 & 0.28 & 1.15 & 47 & 2.38 \\
\hline \multirow[t]{2}{*}{ Late Porphyry } & QVC055 & 55.45 & 0.33 & 1.16 & 35 & 1.41 \\
\hline & QVC029 & 54.68 & 0.24 & 1.12 & 75 & 2.98 \\
\hline Dacite Dyke & QVC040 & 55.52 & 0.33 & 1.16 & 46 & 2.38 \\
\hline
\end{tabular}

*Zircon U-Pb dates obtained by the SHRIMP-RG method

${ }^{\dagger}$ Discordia date is reported, because few concordant dates were obtained 
and Table 1). For both analytical techniques, weighted mean dates are reported here with two uncertainties, the first calculated as the two-sigma error calculated from the weighted mean and the second calculated with a propagated external uncertainty of 2\% (Horstwood et al. 2016). A 2\% external uncertainty was selected based on long-term reproducibility of reference materials across different positions in the sample cell for the LA-ICP-MS system used. The propagation of this added external uncertainty allows systematic bias to be accounted for and allows comparison of dates determined by the two analytical techniques.

The single sample from the monzonite pluton southwest of Toquepala (sample QVC075) gave a weighted mean date of $67.2 \pm 0.79 / 1.56 \mathrm{Ma}(n=14, \mathrm{MSWD}=0.79)$. The two samples from the granodiorite pluton west of Toquepala (samples QVC082, QVC083 and Qu380) yielded weighted means of $60.96 \pm 0.66 / 1.39 \mathrm{Ma}(n=23, \mathrm{MSWD}=1.82)$, $61.64 \pm 0.26 / 1.26 \mathrm{Ma}(n=95, \mathrm{MSWD}=2.63)$ and $60.28 \pm 1.00 / 1.57(n=16$, MSWD $=5.31)$, overlapping within the reported standard error. An aplite dyke (Qu381) cutting the Toquepala Granodiorite gave a similar date to its host rock at $60.18 \pm 0.67 / 1.38 \mathrm{Ma}(n=14$, MSWD =2.37). The Quellaveco Granodiorite (samples QVC028 and Qu008) yielded a weighted mean date of $58.99 \pm 0.23 / 1.20 \mathrm{Ma}(n=94, \mathrm{MSWD}=5.41)$ and a discordia date of $59.99 \pm 0.89 / 1.49(n=12$, MSWD $=0.81)$.

The Granodiorite Porphyry at Quellaveco (sample QVC091) gave a weighted mean date of $58.09 \pm 0.32 / 1.25 \mathrm{Ma}(n=42, \mathrm{MSWD}=3.69)$. The seven remaining samples from the Quellaveco deposit gave weighted mean dates in the range 56-54 Ma (Fig. 4). The Early Porphyry (QVC034) yielded a weighted mean of $54.40 \pm 0.21 / 1.11 \mathrm{Ma}(n=83, \mathrm{MSWD}=3.32)$; the two intermineral Monzonite Porphyry dykes (QVC060 and QVC024) yielded weighted mean dates of $54.88 \pm 0.20 / 1.12 \mathrm{Ma}$ $(n=92, \mathrm{MSWD}=3.18)$ and $54.19 \pm 0.19 / 1.10 \mathrm{Ma}(n=101$, MSWD $=2.74)$, respectively; the Monzodiorite Porphyry dyke (QVC061) yielded an age of 55.26 $\pm 0.28 / 1.15(n=47$, MSWD =2.38); two samples of the Late Porphyry (QVC055 and QVC029) yielded ages of $55.45 \pm 0.33 / 1.16 \mathrm{Ma}$ $(n=35, \mathrm{MSWD}=1.41)$ and $54.68 \pm 0.24 / 1.12 \mathrm{Ma}(n=75$, MSWD $=2.98$ ), respectively; and a post-mineralisation dacite dyke (QVC040) yielded an age of $55.52 \pm 0.33 / 1.16 \mathrm{Ma}$ $(n=46, \mathrm{MSWD}=2.38)$.

\section{Whole-rock chemistry}

The 71 samples analysed show a relatively restricted range of compositions in terms of $\mathrm{SiO}_{2}$ (mostly 60-70 wt.\%) and $\mathrm{MgO}$ (mostly 1-3 wt.\%). The Quellaveco porphyry samples are all granodioritic ( $>62 \mathrm{wt} . \% \mathrm{SiO}_{2}$ ), whereas the Yarabamba Batholith samples exhibit a wider range in major element composition, and classify as diorites, monzonites, granodiorites and one granite on a TAS plot (Fig. 5). The Yarabamba Batholith samples tend to be slightly less evolved (60-65 wt.\% $\mathrm{SiO}_{2}$ ) than the Quellaveco porphyry intrusions (63-69 wt.\% $\mathrm{SiO}_{2}$ ). Key differences are observed between the regional Yarabamba samples and Quellaveco rocks (Figs. 6 and 7). The regional Yarabamba samples exhibit shallowly-sloping LREE and relatively flat HREE patterns $(\mathrm{La} / \mathrm{Yb}<10, \mathrm{Gd} / \mathrm{Yb}<2)$, low $\mathrm{Sr} / \mathrm{Y}$ ratios $(\mathrm{Sr} / \mathrm{Y}<40)$, and distinct, negative $\mathrm{Eu}$ anomalies $\left(\mathrm{Eu} / \mathrm{Eu}^{*}<0.85\right)$. The Quellaveco Granodiorite and all Quellaveco porphyry samples are characterised by steeply-sloping and/or listric REE patterns $(\mathrm{La} / \mathrm{Yb}>14, \mathrm{Gd} / \mathrm{Yb}>2)$, high $\mathrm{Sr} / \mathrm{Y}$ ratios $(>40)$ and suppressed or absent negative Eu anomalies (Eu/ $\mathrm{Eu}^{*}>0.9$ ). Clear distinctions in other trace elements are also observed: the Quellaveco Granodiorite and porphyries are depleted in $\mathrm{TiO}_{2}(<0.6 \mathrm{wt} . \%), \mathrm{Nb}(<5 \mathrm{ppm})$, Ta $(<0.3 \mathrm{ppm}), \mathrm{Hf}(<4 \mathrm{ppm}), \mathrm{Th}(<6 \mathrm{ppm}), \mathrm{U}(<2.5 \mathrm{ppm})$ and $\mathrm{Zr}(<150 \mathrm{ppm})$ relative to the regional Yarabamba rocks.

\section{Zircon trace element chemistry}

Zircon trace element data show systematic trends with positive correlations between $\mathrm{Hf}$ and $\mathrm{Yb} / \mathrm{Gd}$ (Fig. 8a), and between $\mathrm{Th} / \mathrm{U}$ and $\mathrm{Ti}$ (Fig. 8b). However, in terms of several parameters (particularly $\mathrm{Ti}$ and $\mathrm{Eu} / \mathrm{Eu}^{*}$ ), the zircons can be separated into two, chemically-distinct groups (Fig. 8c, d).

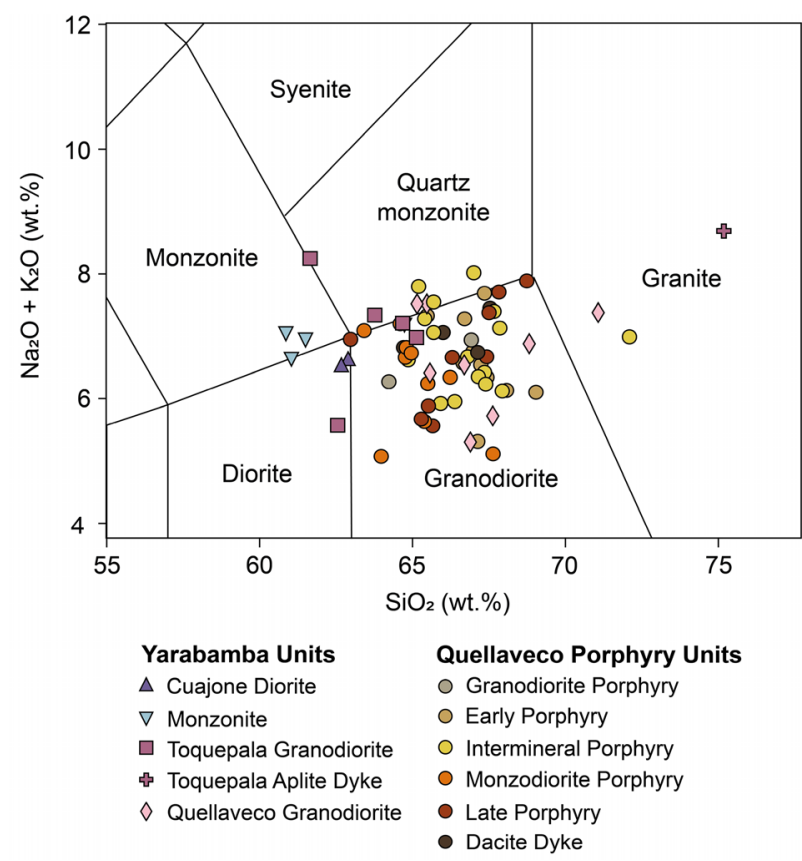

Fig. 5 Plutonic total alkali vs. silica (TAS) diagram after Middlemost (1994). The samples studied from Quellaveco predominantly classify as sub-alkaline and intermediate-felsic (granodiorites), whereas the samples from the Yarabamba Batholith show a greater range in compositions (diorites, monzonites, granodiorites) 

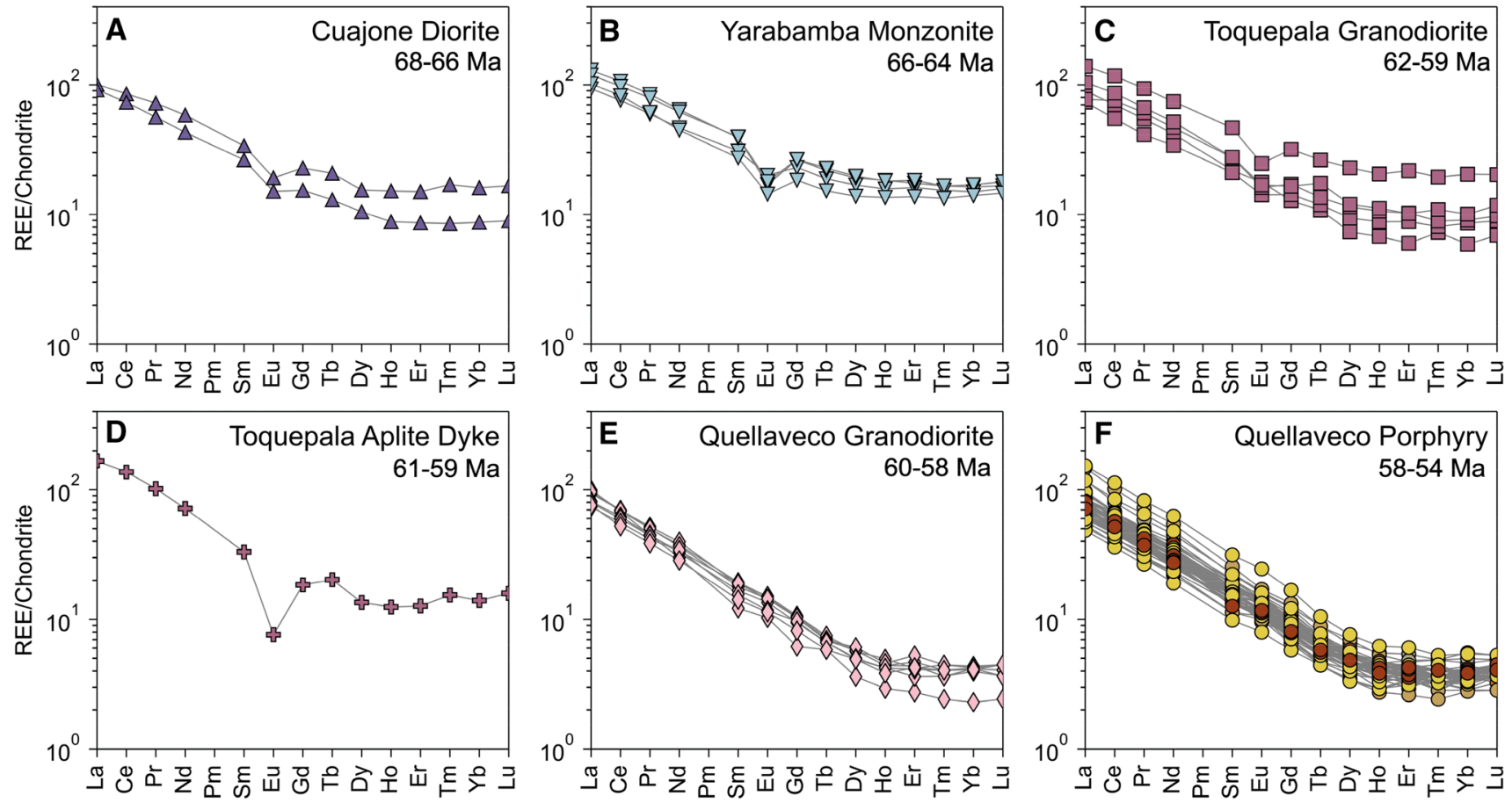

Fig. 6 Chondrite-normalised (Sun and McDonough 1995) whole-rock REE plots for the rocks analysed with their approximate age ranges

High Ti (5-20 ppm) and low Eu/Eu* (0.10-0.35) characterise those from the regional Yarabamba rocks, and low $\mathrm{Ti}$ $(<9 \mathrm{ppm})$ and high $\mathrm{Eu} / \mathrm{Eu}^{*}(0.3-0.7)$ typify zircons from the Quellaveco Granodiorite and porphyry units. Zircons from the eight Quellaveco porphyry intrusions cannot be distinguished; those from the Quellaveco Granodiorite overlap with the porphyries but extend to lower and more restricted Hf (9000-11,000 ppm) and Ti contents (3-8 ppm), and higher and more restricted $\mathrm{Th} / \mathrm{U}$ ratios $(0.5-1.3)$.

Core and rim analyses were performed on a sub-set of zircon crystals that showed variable intra-grain trends (Fig. 9). In the regional Yarabamba rocks, zircon Eu/Eu* $\left(\mathrm{Eu} / \mathrm{Eu}^{*}{ }_{\text {zircon }}\right)$ remains low $(<0.4)$ and there is a general increase in Hf from core to rim (Fig. 9a). In the Quellaveco Granodiorite, there is a lot of variability in core-rim Eu/ $\mathrm{Eu}^{*}$ and Hf trends (Fig. 9b). Conversely, Eu/Eu* ${ }_{\text {zircon }}$ in the Quellaveco porphyry intrusions more consistently decreases from core to rim, coupled with an increase in Hf (Fig. 9c).

\section{Discussion}

\section{Timescale of assembly of the Yarabamba Batholith and emplacement of the Quellaveco porphyries}

Many of the reported weighted mean ${ }^{206} \mathrm{~Pb} /{ }^{238} \mathrm{U}$ zircon dates return MSWDs that are greater than the acceptable MSWD expected for the number of data points (Wendt and Carl
1991). This either indicates that the overdispersion is the result of real geological scatter or an underestimation of the uncertainties of each spot analysis. While it is difficult to exclude real geological scatter as the main cause of the overdispersion, the similar MSWDs and the normal distribution of the data for each sample suggests that under-propagated uncertainties on each spot may play a more significant role, rather than continuous zircon crystallisation over extended durations (e.g., Schoene 2014; Large et al. 2020). We provide recalculated uncertainties of each grain to fit the criteria of a single zircon population (see Supplementary Material 1). However, recalculating the weighted means and standard errors with theoretically higher uncertainties on each date does not change the main findings of the study.

The reported weighted mean dates for the Yarabamba intrusive phases and the Quellaveco porphyry units represent the average age of zircon crystallisation but also constrain the age of emplacement, since the uncertainties on the weighted mean of each intrusive phase are greater than the typical hundred kyr duration of zircon crystallisation in mid-upper crustal magma reservoirs (e.g.,Schoene et al. 2012; Wotzlaw et al. 2013; Samperton et al. 2015; Large et al. 2020). We herein refer to the weighted mean dates as the age of emplacement.

The emplacement ages determined for the thirteen samples from the Yarabamba Batholith (Fig. 4), in combination with their spatial separation, cross-cutting relationships and previously determined U-Pb ages (Simmons 2013), 

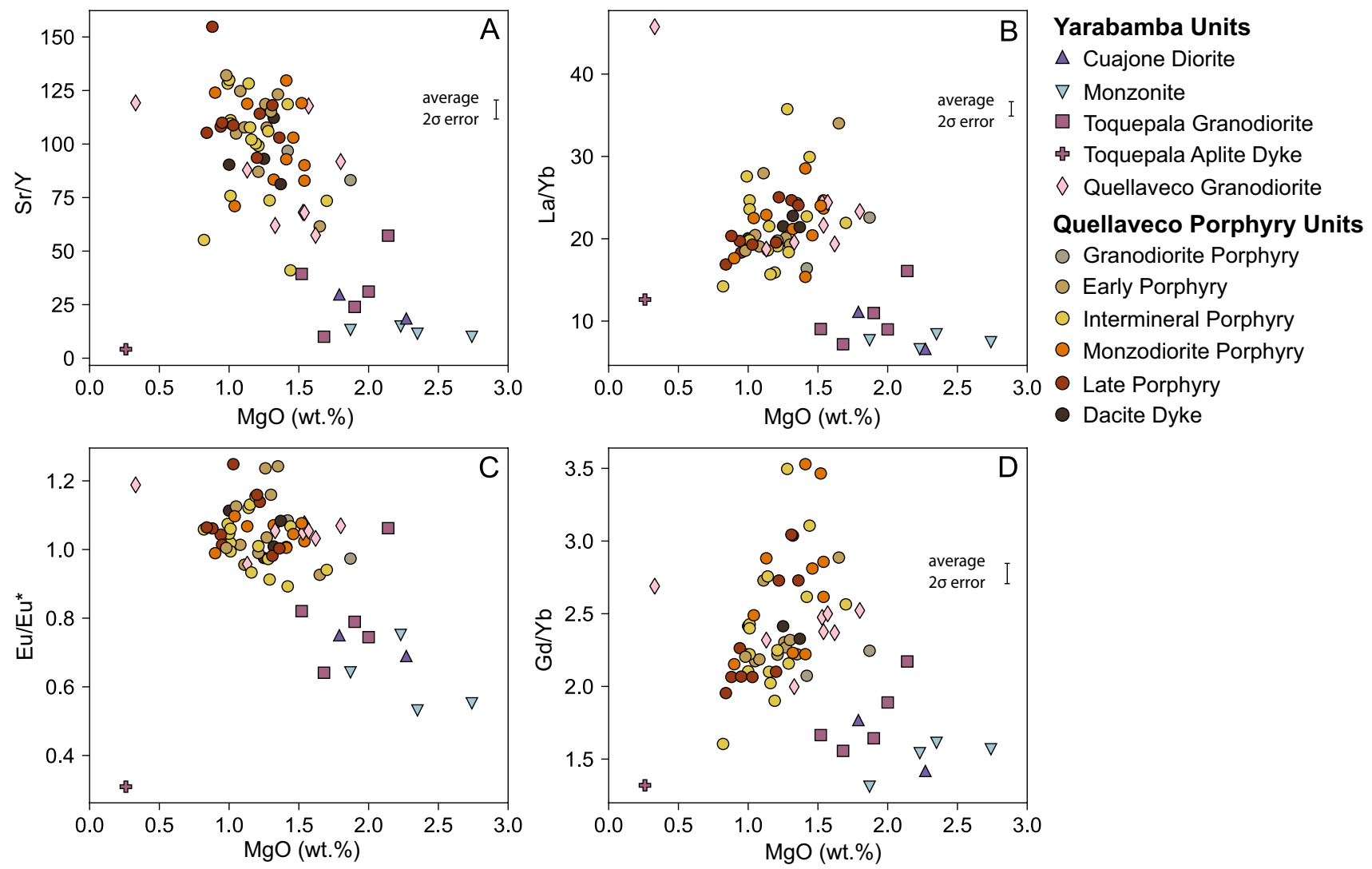

Fig. 7 Geochemical composition of Yarabamba Batholith units (preore) and the Quellaveco porphyry units (syn-ore) showing differences in trace element ratios with $\mathrm{MgO}$ (a) $\mathrm{Sr} / \mathrm{Y}$, (b) $\mathrm{La} / \mathrm{Yb}$, (c) $\mathrm{Eu} / \mathrm{Eu}^{*}$, (d)
$\mathrm{Gd} / \mathrm{Yb}$. Error bars show average $2 \sigma$ error (errors for $\mathrm{MgO}$ and $\mathrm{Eu} /$ Eu* are smaller than the symbol size)

that mineralisation occurred over a timescale smaller than the analytical error for the $\mathrm{U}-\mathrm{Pb}$ methodology used here. The emplacement ages reported here are consistent within uncertainty with previous work on the deposit (Sillitoe and Mortensen 2010; Simmons 2013), with the exception of the "Early Porphyry" we sampled which is considerably younger (by $~ 4 \mathrm{Myr}$ ) than the LA-ICP-MS U-Pb date of $58.41 \pm 0.53$ Ma for an "Early Porphyry" reported by Sillitoe and Mortensen (2010). However, our results are consistent with data reported for the "Early Porphyry" by Simmons (2013), suggesting that Sillitoe and Mortensen (2010) sampled an older intrusive phase.

The emplacement ages determined for the Quellaveco porphyries overlap within uncertainty with those for the neighbouring deposits of Cuajone (56.5-53.0 Ma) and Toquepala (57.0-54.0 Ma) (Fig. 4; Simmons et al. 2013). The resolution of the current dates is insufficient to establish the degree of contemporaneity of the three mineralisation centres (e.g., Large et al. 2020); however, the new ages suggest that the magmatic processes that were conducive to porphyry $\mathrm{Cu}-\mathrm{Mo}$ deposit formation occurred broadly synchronously on a district-scale, in at least these three 

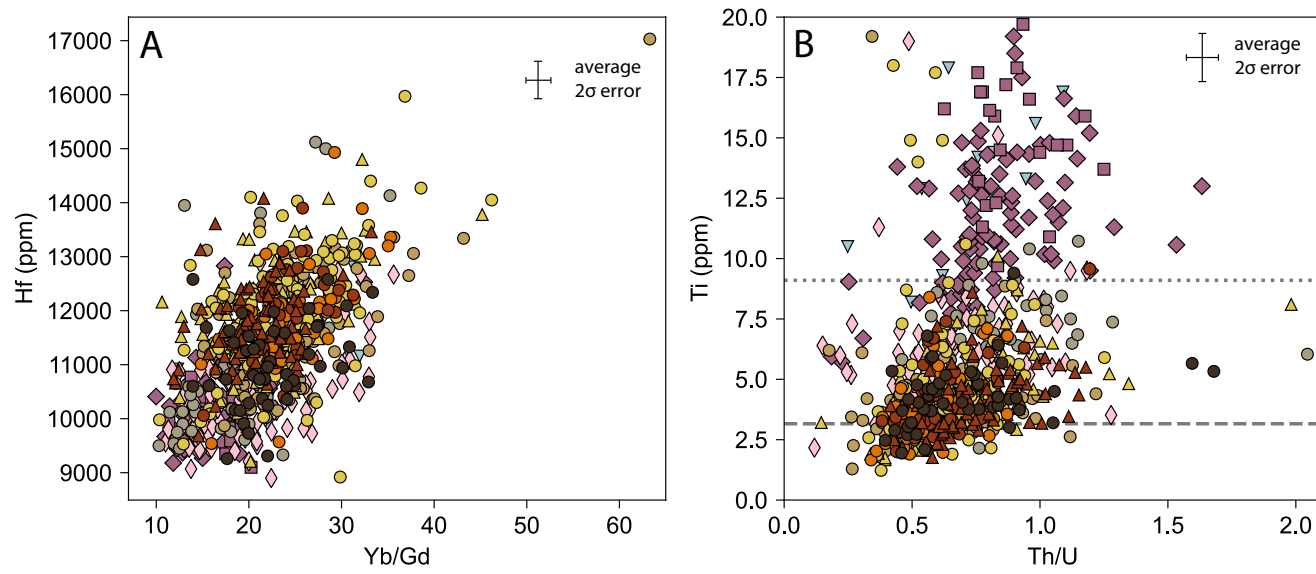

Yarabamba Units

$\nabla$ Monzonite (QVC075)

- Toquepala Granodiorite (QVC082)

$\diamond$ Toquepala Granodiorite (QVC083)

$\diamond$ Quellaveco Granodiorite (QVC028)

Quellaveco Porphyry Units

- Granodiorite Porphyry (QVC091)

- Early Porphyry (QVC034)

O Intermineral 1 (QVC060)

$\triangle$ Intermineral 2 (QVC024)

- Monzodiorite (QVC061)

- Late Porphyry (QVC055)

$\Delta$ Late Porphyry (QVC029)

- Dacite Dyke (QVC040)

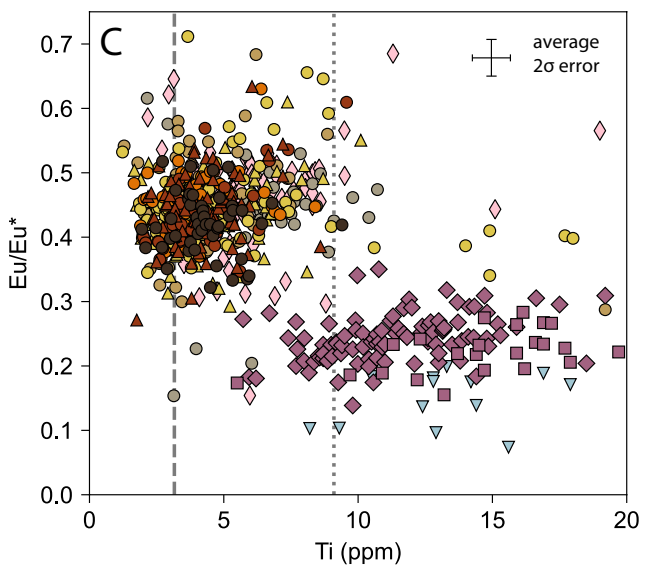

Fig. 8 Zircon composition plots for (a) Eu/Eu* vs. Hf, (b) Eu/Eu* vs. $\mathrm{Ti}$, where lines are temperatures $\left(\right.$ dotted $=800{ }^{\circ} \mathrm{C}$, dashed $=700{ }^{\circ} \mathrm{C}$ ) calculated using Ti-in-zircon thermometer assuming $\alpha_{\mathrm{TiO} 2}=0.5$ and
$\alpha_{\mathrm{SiO} 2}=1.0$ (Ferry and Watson 2007), (c) Ti vs. Th/U and (d) Yb/Gd vs. Hf. Error bars show average $2 \sigma$ error

giant porphyry $\mathrm{Cu}-\mathrm{Mo}$ deposits at $\sim 55 \mathrm{Ma}$. In addition, the porphyry intrusive phases at Quellaveco provide a series of aliquots of the underlying magma system that released magmatic-hydrothermal fluid resulting in mineralisation.

The observed differences in whole-rock compositions between the Yarabamba and Quellaveco porphyry suites reflect a distinct change in magma chemistry at $\sim 60 \mathrm{Ma}$, characterised by a transition to higher $\mathrm{Sr} / \mathrm{Y}, \mathrm{La} / \mathrm{Yb}, \mathrm{Eu} / \mathrm{Eu}^{*}$ and $\mathrm{Gd} / \mathrm{Yb}$ (Fig. 7), as well as generally more evolved major element compositions (e.g., $\mathrm{SiO}_{2}>65$ wt.\%). These differences could reflect changes in intra-crustal magma evolution processes and/or changes in the mantle source composition. The relatively evolved and limited range in $\mathrm{SiO}_{2}$ and $\mathrm{MgO}$ concentrations of the studied samples does not permit a rigorous assessment of whether the recorded geochemical changes are linked to variable primary melt compositions and mantle source processes. However, the concomitant change in $\mathrm{SiO}_{2}$ content with the shifts in $\mathrm{Sr} / \mathrm{Y}, \mathrm{La} / \mathrm{Yb}$ and $\mathrm{Eu} / \mathrm{Eu}^{*}$ provides evidence that such signatures more likely reflect intra-crustal evolution. Furthermore, in modern arcs, there is a broad correlation between $\mathrm{Sr} / \mathrm{Y}$ and $\mathrm{La} / \mathrm{Yb}$ with samples provide critical petrogenetic information on the magmatic evolution that led up to the formation of the three 


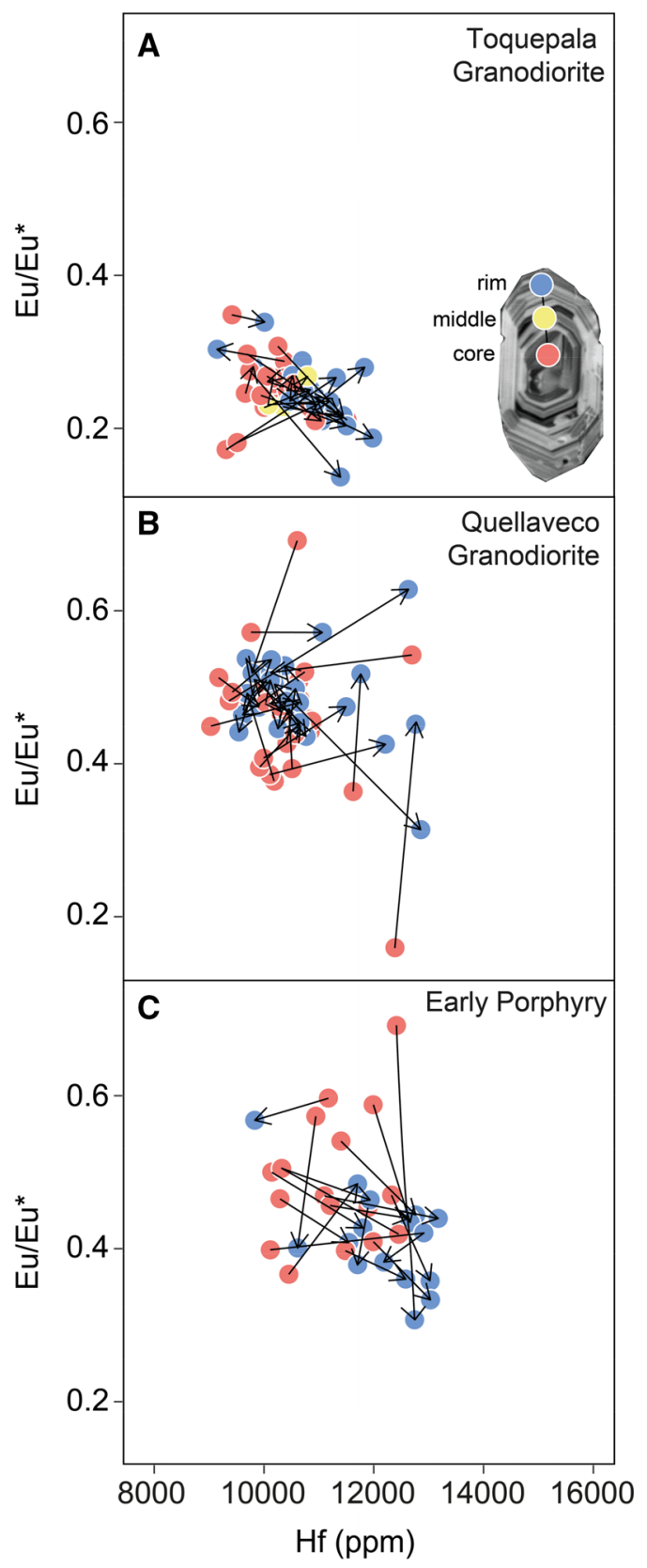

Fig. 9 Core-rim $\mathrm{Eu} / \mathrm{Eu}^{*}$ vs. Hf composition of zircon crystals for (a) Toquepala Granodiorite (QVC083), (b) Quellaveco Granodiorite (QVC028), (c) Early Porphyry (QVC034). Red circles indicate core analyses, blue circles-rims, yellow-midway between core and rim. Lines join analyses from the same crystal and arrows point from core to rim

crustal thickness, and therefore, these parameters may be linked to the depth of intra-crustal magma evolution (Chiaradia et al. 2015; Chapman et al. 2015; Profeta et al. 2015). Thus, while a change in mantle source cannot be excluded as a control on the shift in magma geochemistry observed in this study, we suggest intra-crustal processes primarily drove this fundamental change.
Experimental studies (e.g.,Müntener and Ulmer 2018; Nandedkar et al. 2014) have demonstrated that in hydrous melts $\left(>4 \mathrm{wt} . \% \mathrm{H}_{2} \mathrm{O}\right)$, at pressures found at depth in thickened arc crust $(>0.7 \mathrm{GPa}$ ), amphibole (in which Y, MREEs and HREEs are compatible: Nandedkar et al. 2016) is stabilised as a liquidus phase at the expense of plagioclase (in which Sr and Eu are compatible; Aigner-Torres et al. 2007) and clinopyroxene (in which Y, MREEs and HREEs are weakly compatible; Luhr et al. 1984a, b). This fractionation of an amphibole-dominant assemblage from a primitive arc magma can account for the high $\mathrm{Sr} / \mathrm{Y}$ and $\mathrm{La} / \mathrm{Yb}$ values observed in global porphyry $\mathrm{Cu}$ datasets (Richards and Kerrich 2007), and suppression of plagioclase would further increase $\mathrm{Sr} / \mathrm{Y}$ and increase $\mathrm{Eu} / \mathrm{Eu}$ *. However, the increases in $\mathrm{Sr} / \mathrm{Y}$ and $\mathrm{La} / \mathrm{Yb}$ observed here are accompanied by an increase in $\mathrm{Gd} / \mathrm{Yb}$ (Fig. 7), which is not characteristic of an amphibole-dominated fractionation pathway, because amphibole preferentially partitions Gd over $\mathrm{Yb}$ (e.g., Nandedkar et al. 2016). This may be accounted for by the additional presence of garnet in the fractionating assemblage (or as a residual phase in equilibrium with the magma), which has partition coefficients an order of magnitude higher for HREEs than for MREEs (e.g., Green et al. 2000). Garnet has been stabilised in experimental studies at either high pressures $(>0.8 \mathrm{GPa})$ or at high melt water contents (> $8 \mathrm{wt} . \%$ ) (Müntener et al. 2001; Alonso Perez et al. 2009). The traceelement geochemical evolution, therefore, suggests a change in the fractionating assemblage in the lower crust, as a result of increased pressure and/or melt water contents, stabilising amphibole \pm garnet at the expense of plagioclase.

In porphyry-related rocks, trace element signatures such as high $\mathrm{Sr} / \mathrm{Y}$ have been shown to become more pronounced during magmatic differentiation (Loucks 2014). Thus, it is possible to suggest that the absence of these signatures in the older, Yarabamba rocks is because they had undergone less magmatic differentiation $\left(<65 \mathrm{wt} . \% \mathrm{SiO}_{2}\right)$ than the younger, more evolved ( $>65$ wt.\% $\mathrm{SiO}_{2}$ ), high $\mathrm{Sr} / \mathrm{Y}$ Yarabamba and Quellaveco rocks. However, this amphibole fractionation signature would be imparted early in magma evolution, because amphibole generally crystallises early in experimental studies at lower crustal pressures (e.g.,Nandedkar et al. 2014; Melekhova et al. 2017; Ulmer et al. 2018). A change in melt silica content from 60 to $65 \mathrm{wt} . \% \mathrm{SiO}_{2}$ would not change the fractionating assemblage from plagioclase- to amphibole-dominated, and, therefore, cannot solely explain the change in trace element chemistry. Instead, the stabilisation of amphibole in lower crustal cumulates at the expense of clinopyroxene would drive the derivative melts to granodioritic compositions (e.g., Klaver et al. 2018) which could explain the more evolved major element composition of the batholith after $\sim 60 \mathrm{Ma}$.

We, therefore, interpret the inferred change in the fractionating assemblage as most likely related to an increase in 
pressure and melt water content, reflecting an increase in the depth of the locus of magma evolution in the lower crust. This could be the result of a stronger compressional tectonic regime, causing the timescale of magma storage and differentiation in the lower crust to increase and allowing residual melts to attain higher concentrations of incompatible trace elements (e.g., Annen et al. 2006) as well as water. The marked change in the geochemistry of magmas is broadly coincident with a clockwise rotation of the convergence of the subducting Nazca plate towards more orthogonal subduction at $\sim 59$ Ma which caused a significant increase in the rate of convergence (Pardo-Casas and Molnar 1987; Jaillard and Soler 1996). This initiated an episode of major compression in the Central Andes-referred to as the earliest phase of the Incaic orogeny, termed 'Incaic I' (59-55 Ma; Noble et al. 1985; Jaillard and Soler 1996; Benavides-Cáceres 1999). An equivalent tectonic phase in Northern Chile, the ' $\mathrm{K}-\mathrm{T}$ ' compressive event, has been attributed to the formation of a porphyry $\mathrm{Cu}$ belt consisting of Relincho (61 Ma), Spence (57 Ma) and Cerro Colorado (52 Ma) (Sillitoe and Perelló 2005; Mpodozis and Cornejo 2012).

The transition in melt compositions towards high $\mathrm{Sr} / \mathrm{Y}$ and $\mathrm{La} / \mathrm{Yb}$ predates the onset of the bulk of mineralisation in the district ( $55 \mathrm{Ma}$; Sillitoe and Mortensen 2010$)$ by $\sim 3.5 \pm 1.7 \mathrm{Myr}$. The delay suggests that despite the emplacement of magmas typically associated with porphyry $\mathrm{Cu}$ mineralisation in the shallow crust by $\sim 59 \mathrm{Ma}$ (the Quellaveco Granodiorite), this was insufficient to generate major porphyry systems at this time. Perhaps, the Quellaveco Granodiorite was sourced from an upper crustal magma reservoir that was not yet capable of supplying the heat and volume of fluid necessary for effective porphyry $\mathrm{Cu}$ mineralisation (Chelle-Michou et al. 2017). We envisage this extended time period as a necessary priming phase, where growth and recharge of the lower crustal magma reservoir allowed a sufficient volume of hydrous melt $\left(>800 \mathrm{~km}^{3}\right)$ to accumulate at depth (Rohrlach and Loucks 2005; Chiaradia and Caricchi 2017). Such magmas would be rapidly and episodically transferred to upper crustal levels $(<500 \mathrm{Kyr}$; Chelle Michou et al. 2017), where cooling and degassing would allow efficient migration and accumulation of a magmatic volatile phase at apices of the batholith (Huber et al. 2012; Parmigiani et al. 2016; Korges et al. 2020). Laterally focused fluid outbursts from the roof of the batholith would provide the source of melt and fluid to initiate and sustain the magmatic-hydrothermal system at Quellaveco (LamyChappais et al. 2020).

\section{The zircon record of the evolving Yarabamba Batholith and Quellaveco porphyry system}

The trace element compositions of zircons not only record the trace element budget of the melts building the
Yarabamba Batholith and Quellvaco porphyry $\mathrm{Cu}$ deposit, but also provide insights into the evolution of each intrusive phase from zircon saturation to the solidus. High precision zircon $\mathrm{U}-\mathrm{Pb}$ studies have documented that zircons within a single sample of an intrusive or volcanic rock typically record several hundred kyr of magmatic history (e.g.,Schoene et al. 2012; Wotzlaw et al. 2013; Samperton et al. 2015; Buret et al. 2016; Large et al. 2018). Some of these studies have resolved systematic trends in trace elements in zircon with time, indicating that zircon can record melt compositional evolution over such timescales. Furthermore, core to rim analyses on single grains provides a tool to track a relative liquid line of descent during zircon growth.

Here, zircon data between samples of different age (Yarabamba units vs. Quellaveco porphyry units, Fig. 8), and within individual grains (Fig. 9), show systematically increasing $\mathrm{Yb} / \mathrm{Gd}$, decreasing $\mathrm{Th} / \mathrm{U}$, increasing $\mathrm{Hf}$ and decreasing $\mathrm{Ti}$. These trends are consistent with a previous zircon chemistry study of the Quellaveco intrusive complex (Simmons 2013) and are interpreted to reflect the changing trace element composition of the residual melt during zircon growth. Both increasing $\mathrm{Yb} / \mathrm{Gd}$ and decreasing $\mathrm{Th} / \mathrm{U}$ suggest the co-crystallisation of titanite and/or apatite which preferentially partition $\mathrm{Gd}$ over $\mathrm{Yb}$ and Th over $\mathrm{U}$ (Wotzlaw et al. 2013; Samperton et al. 2015; Buret et al. 2016; Loader et al. 2017; Rezeau et al. 2019). These ratios involve isovalent cations, which should minimise the effect of other potential influences on partition coefficients such as temperature and melt composition. Increasing $\mathrm{Hf}$ is consistent with progressive magma evolution, because $\mathrm{Hf}$ is incompatible in all common rock-forming minerals except zircon (Claiborne et al. 2006) and the partition coefficient of Hf would be expected to increase significantly with decreasing temperature (Blundy and Wood 1994). Titanium in zircon is typically considered as a proxy for the temperature of zircon crystallisation (Ferry and Watson 2007), thus the trend of decreasing $\mathrm{Ti}$ (which correlates with Th/U; Fig. 8b), could indicate progressive cooling of the melt after zircon saturation. Overall, these systematic trends are consistent with melt evolution towards more evolved compositions during cooling and crystallisation of the magmatic system after zircon saturation. Although systematic bivariate trends in zircon trace element chemistry are observed in some parameters, a more bimodal distribution is observed for $\mathrm{Eu} / \mathrm{Eu}^{*}$, and less strongly for Ti (Fig. 8c, d), which increase and decrease, respectively after $\sim 60 \mathrm{Ma}$. These two zircon populations correspond to samples that define the change in whole-rock chemistry after $\sim 60 \mathrm{Ma}$ (Fig. 7), with higher Eu/Eu* ${ }_{\text {zircon }}$ in the younger rocks correlating with higher whole-rock Eu/ Eu* (Fig. 10). Based on our interpretation of the wholerock signatures, this coupling suggests that the change in $\mathrm{Eu} /$ $\mathrm{Eu}^{*}{ }_{\text {zircon }}$ after $\sim 60 \mathrm{Ma}$ is the result of a change in early, deep 
crustal processes, prior to magma emplacement, cooling and zircon saturation in the upper crust.

Lower Ti concentrations in zircons associated with porphyry $\mathrm{Cu}$ deposits compared with precursor granitoids has been observed elsewhere—at Yanacocha (Peru), Yerington (USA) and Highland Valley (Canada) (Dilles et al. 2015; Lee et al. 2020) - and may, therefore, be an indicator of petrogenetic processes that are linked to the formation of giant porphyry $\mathrm{Cu}$ systems. As noted above, the decrease in zircon Ti may reflect a decrease in the temperature of the melts from which zircon crystallised (Ferry and Watson 2007). It could be speculated that the inferred higher melt water contents of the magmas that formed the Quellaveco Granodiorite and the porphyry units, may have delayed zircon saturation to lower temperatures (Harrison and Watson 1983), however more recently it has been suggested that melt water content does not exert a major control on zircon saturation (Boehnke et al. 2013). Calculated temperatures using the Ti-in-zircon thermometer, assuming activities of $\mathrm{TiO}_{2}$ and $\mathrm{SiO}_{2}$ of 0.5 and 1.0, yield temperatures that range from 650 to $800{ }^{\circ} \mathrm{C}$ for the rocks younger than $\sim 60 \mathrm{Ma}$ (Quellaveco rocks) and from 750 to $890^{\circ} \mathrm{C}$ for the Yarabamba rocks older than $\sim 60 \mathrm{Ma}$ (see Supplementary Material 2). The occurrence of many below/near-solidus temperatures suggests that other variables (e.g., variable activities of $\mathrm{SiO}_{2}$ and $\mathrm{TiO}_{2}$, additional substitution mechanisms for $\mathrm{Ti}$ ) may influence $\mathrm{Ti}$ concentrations in zircon (Fu et al. 2008). The melt $\mathrm{TiO}_{2}$

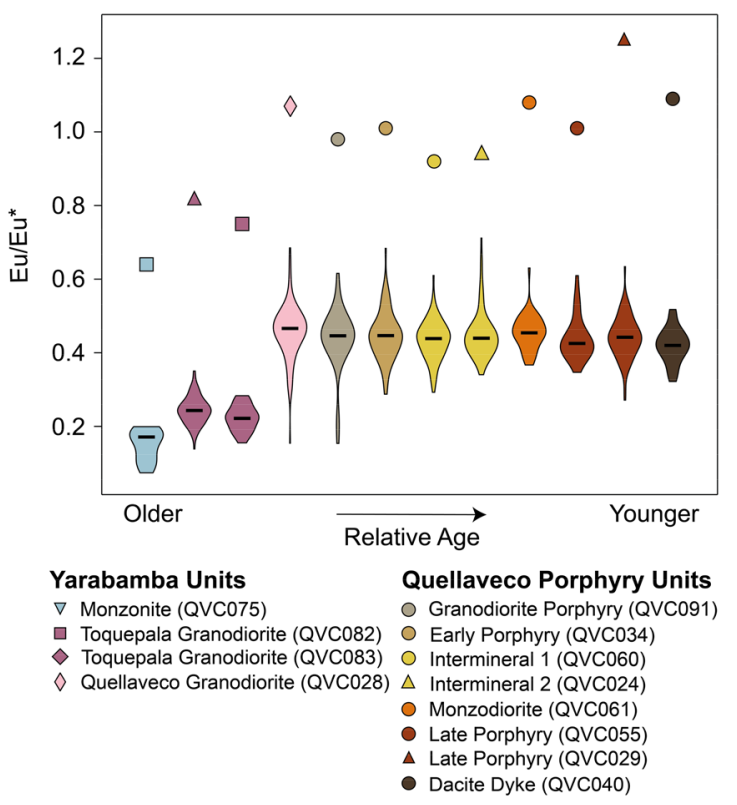

Fig. $10 \mathrm{Eu} / \mathrm{Eu}^{*}$ in zircon (density bars-horizontal lines show median values) and whole-rocks (small symbols), ranked by relative age as determined by geochronology for the Yarabamba samples and by cross-cutting relationships for the Quellaveco porphyry intrusions. Both zircons and whole-rocks show a proportional increase in $\mathrm{Eu} / \mathrm{Eu}^{*}$ from the emplacement of the Quellaveco Granodiorite and onwards activity can vary between different granitic melts and at different stages of melt differentiation (e.g., between 0.1 and 0.6; Schiller and Finger 2019) and can, therefore, influence calculated Ti-in-zircon temperatures. Lower Ti activity in the melt could be the result of stabilising amphibole and/ or biotite (in which Ti is compatible; e.g.,Nandedkar et al. 2016; Azadbakht et al. 2020) as earlier and more abundant crystallising phases in the inferred higher water content melts after $\sim 60 \mathrm{Ma}$. Therefore, these estimated temperatures should be treated with caution, and the origin of the marked decrease in zircon $\mathrm{Ti}$ concentrations at $\sim 60 \mathrm{Ma}$ could be related to temperature, a change in the $\mathrm{TiO}_{2}$ activity of the melt or other unknown factors. Regardless of the origin, lower Ti concentrations in zircon appear to be a potential empirical discriminator of granitoids associated with giant porphyry $\mathrm{Cu}$ deposits.

\section{Modelling the effects of melt compositions and oxidation state on zircon Eu/Eu*}

Higher Eu/Eu* ${ }_{\text {zircon }}$ in igneous rocks associated with porphyry $\mathrm{Cu}$ deposits, compared to precursor or unrelated igneous rocks, has been observed in several studies (e.g.,Ballard et al. 2002; Liang et al. 2006; Dilles et al. 2015; Shen et al. 2015; Lee et al. 2017; Loader et al. 2017) and has been attributed by many authors to an increase in melt $f \mathrm{O}_{2}$. However, it is clear that $f \mathrm{O}_{2}$ alone cannot account for all of the variability in $\mathrm{Eu} / \mathrm{Eu}^{*}{ }_{\text {zircon, }}$, because values above 1 are reported (e.g., Loader et al. 2017); a limiting value for highly oxidised, primitive melts containing essentially only $\mathrm{Eu}^{3+}$ is 1 . An alternative factor that can strongly influence $\mathrm{Eu} /$ $\mathrm{Eu}^{*}{ }_{\text {zircon }}$ that we consider in more detail below is the intrinsic $\mathrm{Eu} / \mathrm{Eu}^{*}{ }_{\text {melt }}$, itself a function of prior magmatic evolution (e.g.,Trail et al. 2012; Buret et al. 2016; Loader et al. 2017; Rezeau et al. 2019).

Theoretically, changes in the Eu anomaly of zircon can reflect changes in either: (1) the Eu anomaly of the melt; or (2) the zircon-melt partition coefficient for $\mathrm{Eu}\left(\mathrm{D}_{\mathrm{Eu}}\right)$ relative to the partition coefficients of its neighbouring REEs $\left(\mathrm{D}_{\mathrm{Sm}}\right.$ and $\left.\mathrm{D}_{\mathrm{Gd}}\right)$. Experimental studies have demonstrated that increasing melt $f \mathrm{O}_{2}$ increases $\mathrm{D}_{\mathrm{Eu}}$ towards $\mathrm{D}_{\mathrm{Sm}}$ and $\mathrm{D}_{\mathrm{Gd}}$ because of a concurrent increase in the proportion of $\mathrm{Eu}^{3+}$ in the melt which partitions more strongly into zircon than $\mathrm{Eu}^{2+}$ (Burnham and Berry 2012), thus an $f \mathrm{O}_{2}$ control on $\mathrm{Eu} / \mathrm{Eu}^{*}{ }_{\text {zircon }}$ is expected. To assess the relative influence of changes in $\mathrm{Eu} / \mathrm{Eu}^{*}{ }_{\text {melt }}$ and $f \mathrm{O}_{2}$ on $\mathrm{Eu} / \mathrm{Eu}^{*}{ }_{\text {zircon }}$, a model was developed that calculates theoretical Eu/Eu* ${ }_{\text {zircon }}$ as a function of $\mathrm{Eu} / \mathrm{Eu}^{*}{ }_{\text {melt }}, \mathrm{fO}_{2}$, temperature and optical basicity (a measurement of melt structure) (Fig. 11). The partition coefficient of Eu into zircon $\left(\mathrm{D}_{\mathrm{Eu}(\mathrm{zircon})}\right)$ is calculated in the model as a function of the partition coefficients for $\mathrm{Eu}^{2+}$ and $\mathrm{Eu}^{3+}$ into zircon $\left(\mathrm{D}_{\mathrm{Eu} 2+}\right.$ and $\left.\mathrm{D}_{\mathrm{Eu} 3+}\right)$ and the $\mathrm{Eu}^{2+} /$ 


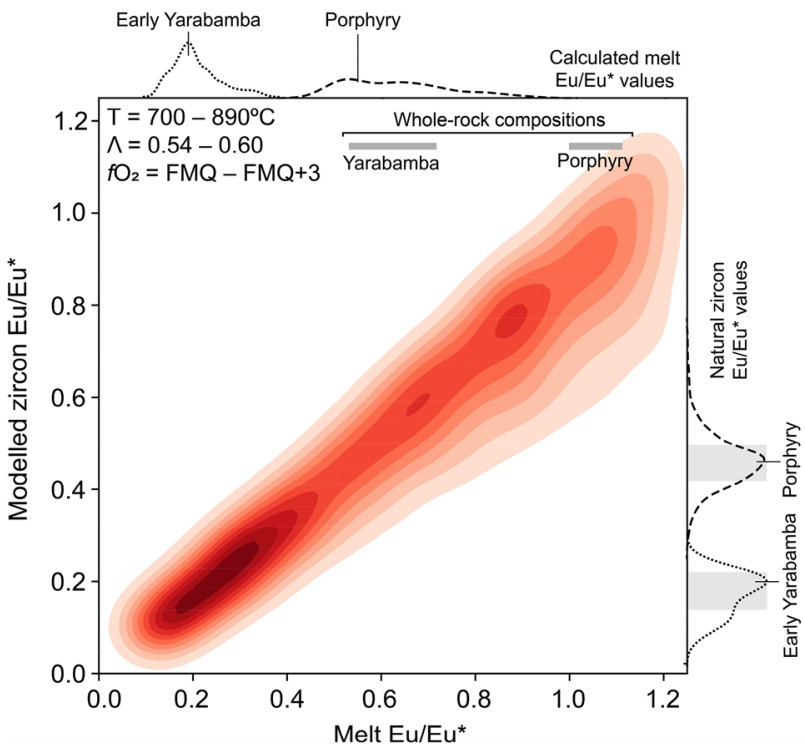

Fig. 11 Heat map of modelled $\mathrm{Eu} / \mathrm{Eu}^{*}{ }_{\text {zircon }}(n=10,000)$ as a function of a range of $\mathrm{Eu} / \mathrm{Eu}^{*}{ }_{\text {melt }}$ compositions using a Monte Carlo simulation, where $\mathrm{Eu} / \mathrm{Eu}^{*}{ }_{\text {melt }}$, temperature $(\mathrm{T})$, optical basicity $(\Lambda)$ and $f \mathrm{O}_{2}$ are varied stochastically in each iteration of the model within the given range. Darker colours illustrate higher density of modelled data points. Modelled Eu/Eu* ${ }_{\text {zircon }}$ shows strong dependence on Eu/ $\mathrm{Eu}_{\text {melt }}^{*}\left(r^{2}=0.87\right)$. Kernel density plot along y-axis shows the density of natural $\mathrm{Eu} / \mathrm{Eu}^{*}{ }_{\text {zircon }}$ for Yarabamba Monzonite (dotted line) and the Quellaveco porphyries (dashed line) fit with a gaussian kernel function. The $\mathrm{Eu} / \mathrm{Eu}^{*}{ }_{\text {melt }}$ that is in equilibrium with these two zircon populations is estimated from the heat map and is displayed as a kernel density plot along the $\mathrm{x}$-axis. The grey bars along the $\mathrm{x}$-axis indicate the interquartile range of the whole-rock Eu/Eu* for Yarabamba Monzonite and the Quellaveco porphyries. The calculated $\mathrm{Eu} / \mathrm{Eu}^{*}{ }_{\text {melt }}$ is considerably lower than the whole-rock $\mathrm{Eu} / \mathrm{Eu}^{*}$ for both populations, indicating that zircons crystallised from a melt that was modified by plagioclase crystallisation without segregation

$\mathrm{Eu}^{3+}$ ratio of the melt. This is formulated as (Wilke and Behrens 1999; Aigner-Torres et al. 2007):

$D_{\mathrm{Eu}(\text { zircon })}=\frac{D_{\mathrm{Eu}^{3+}}+\left(\left(\frac{\mathrm{Eu}^{2+}}{\mathrm{Eu}^{3+}}\right)_{\text {melt }} \times D_{\mathrm{Eu}^{2+}}\right)}{\left(\frac{\mathrm{E}^{2+}}{\mathrm{Eu}^{3+}}\right)_{\text {melt }}+1}$

where $\mathrm{D}_{\mathrm{Eu}}{ }^{2+} \sim 0$, because $\mathrm{Eu}^{2+}$ is essentially incompatible in zircon's structure due to its low charge and large ionic radius. The partition coefficients $\mathrm{D}_{\mathrm{Eu}}{ }^{3+}, \mathrm{D}_{\mathrm{Sm}}$ and $\mathrm{D}_{\mathrm{Gd}}$ were calculated using lattice strain theory by compiling and parameterising the lattice strain fit parameters for zircon (Blundy and Wood 1994; Claiborne et al. 2018). The valence state of $\mathrm{Eu}$ in the melt $\left(\mathrm{Eu}^{2+} / \mathrm{Eu}^{3+}{ }_{\text {melt }}\right)$ was calculated as a function of $\mathrm{fO}_{2}$ using an experimental calibration (Burnham et al. 2015).

To interrogate the sensitivity of $\mathrm{Eu} / \mathrm{Eu}^{*}{ }_{\text {zircon }}$ to $\mathrm{Eu} /$ $\mathrm{Eu}^{*}{ }_{\text {melt }}$, a model was run in which $\mathrm{Eu} / \mathrm{Eu}^{*}{ }_{\text {melt }}$ was varied across an appropriate range of $\mathrm{Eu} / \mathrm{Eu} *$ expected for arc magmas (0.1-1.2), and $\mathrm{Eu} / \mathrm{Eu}^{*}{ }_{\text {zircon }}$ in equilibrium with these melt compositions was calculated. The model used a Monte Carlo approach in which the value of each variable $(\mathrm{Eu} /$ $\mathrm{Eu}^{*}{ }_{\text {melt }}$, temperature, optical basicity and $f \mathrm{O}_{2}$ ) in each iteration of the model is stochastically generated within defined ranges. The model was run 10,000 times and the calculated $\mathrm{Eu} / \mathrm{Eu}^{*}{ }_{\text {zircon }}$ and the conditions in each model iteration were compiled (Fig. 11). Further information on the modelling is available in Supplementary Materials 1 and 3.

This modelling identified a strong dependence of Eu/ $\mathrm{Eu}^{*}{ }_{\text {zircon }}$ on $\mathrm{Eu} / \mathrm{Eu}^{*}{ }_{\text {melt }}\left(r^{2}=0.87\right.$; Fig. 11). Thus, using this relationship, it is possible to estimate $\mathrm{Eu} / \mathrm{Eu}^{*}{ }_{\text {melt }}$ for a natural dataset using measured $\mathrm{Eu} / \mathrm{Eu}^{*}{ }_{\text {zircon}}$. By this method, $\mathrm{Eu} /$ $\mathrm{Eu}^{*}{ }_{\text {melt }}$ (at the time of zircon crystallisation) was estimated from the $\mathrm{Eu} / \mathrm{Eu}_{\text {zircon }}$ measured for the early Yarabamba rocks (Yarabamba Monzonite) and the Quellaveco porphyries (see kernel-density plots in Fig. 11). The estimated $\mathrm{Eu} / \mathrm{Eu}^{*}{ }_{\text {melt }}$ for the Yarabamba Monzonite (interquartile range $=0.18-0.24$ ) and the Quellaveco porphyries (interquartile range $=0.52-0.69$ ) form two, nearly non-contiguous $\mathrm{Eu} / \mathrm{Eu}^{*}{ }_{\text {melt }}$ populations. These two melt populations display significantly lower $\mathrm{Eu} / \mathrm{Eu} *$ than whole-rock $\mathrm{Eu} / \mathrm{Eu}^{*}$ for the Yarabamba Monzonite (interquartile range $=0.55-0.67$ ) and the Quellaveco porphyries (interquartile range $=1.00-1.08$ ), respectively, which is unsurprising given that melt compositions strongly diverge from bulk magma compositions during crustal transit and storage (e.g., Reubi and Blundy 2009). We interpret these low $\mathrm{Eu} / \mathrm{Eu}^{*}{ }_{\text {melt }}$ values, compared to whole-rock $\mathrm{Eu} / \mathrm{Eu}^{*}$, as being due to modification of melt compositions prior to zircon saturation by plagioclase crystallisation during magma ascent and storage in the shallow crust (Sisson and Grove 1993; Waters et al. 2015). Despite this modification of the putative deep crustal signature, the model indicates that zircons in the Yarabamba Monzonite and the Quellaveco porphyries still inherited distinct $\mathrm{Eu} /$ $\mathrm{Eu}^{*}$ signatures, as also recorded by the whole-rock $\mathrm{Eu} / \mathrm{Eu}^{*}$.

The strong control of $\mathrm{Eu} / \mathrm{Eu}^{*}{ }_{\text {zircon }}$ by $\mathrm{Eu} / \mathrm{Eu}^{*}{ }_{\text {melt }}$ predicted by the model does not preclude an additional influence of melt $f \mathrm{O}_{2}$. The model outlined above was re-run using a smaller Eu/Eu* ${ }_{\text {melt }}$ range (0.12-0.70), based on the modelled $\mathrm{Eu} / \mathrm{Eu}^{*}{ }_{\text {melt }}$ derived for the Yarabamba Monzonite and Quellaveco porphyries. Melt $f \mathrm{O}_{2}$ was found to have a weak effect on $\mathrm{Eu} / \mathrm{Eu}^{*}{ }_{\text {zircon }}$ with considerable scatter (Fig. 12), indicating that other parameters (such as $\mathrm{Eu} / \mathrm{Eu}^{*}{ }_{\text {melt }}$ ) have a stronger effect on $\mathrm{Eu} / \mathrm{Eu}^{*}{ }_{\text {zircon}}$. Significantly, an increase in melt $f \mathrm{O}_{2}$ from FMQ to $\mathrm{FMQ}+3$ (the maximum range for arc magmas; Carmichael 1991), cannot solely account for the difference in $\mathrm{Eu} / \mathrm{Eu}^{*}{ }_{\text {zircon }}$ between the early Yarabamba and the Quellaveco porphyry rocks. Furthermore, re-running the model to isolate the individual effect of each intensive parameter on $\mathrm{Eu} / \mathrm{Eu}^{*}{ }_{\text {zircon }}\left(\mathrm{Eu} / \mathrm{Eu}^{*}{ }_{\text {melt }}\right.$, temperature, $f \mathrm{O}_{2}$ and optical basicity) indicates that $\mathrm{Eu} / \mathrm{Eu}^{*}{ }_{\text {melt }}$ has a substantially 


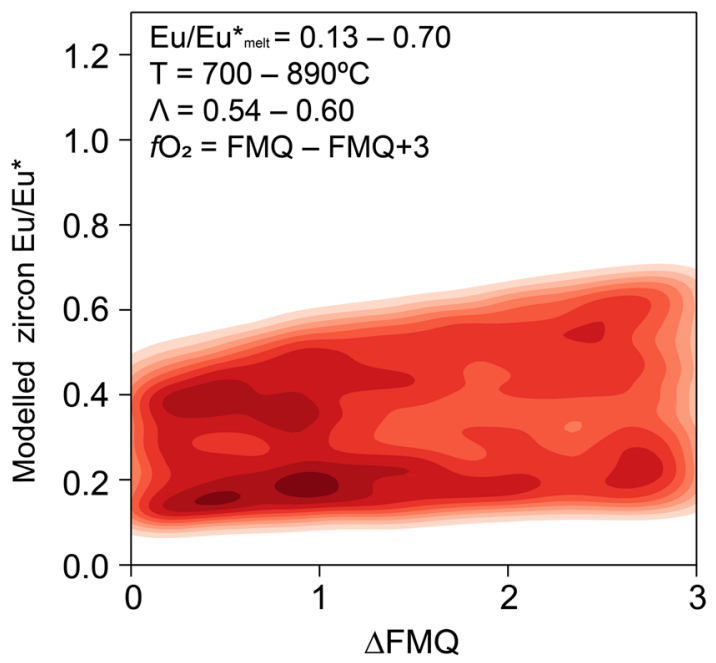

Fig. 12 Heat map of modelled $\mathrm{Eu} / \mathrm{Eu}^{*}{ }_{\text {zircon }}(n=10,000)$ as a function of a range of melt $f \mathrm{O}_{2}$ (relative to the fayalite-magnetite-quartz redox buffer) using a Monte Carlo simulation, where $\mathrm{Eu} / \mathrm{Eu}^{*}{ }_{\text {melt }}$, temperature $(\mathrm{T})$, optical basicity $(\Lambda)$ and $f \mathrm{O}_{2}$ are varied stochastically in each iteration of the model within the given range. The range of $\mathrm{Eu} / \mathrm{Eu}^{*}{ }_{\text {melt }}$ selected is based on the modelled $\mathrm{Eu} / \mathrm{Eu}^{*}{ }_{\text {melt }}$ range for 5th and 95 th percentile for Yarabamba and Quellaveco porphyries, respectively (Fig. 11). Darker colours illustrate higher density of modelled data points

greater levering effect on $\mathrm{Eu} / \mathrm{Eu}^{*}{ }_{\text {zircon }}$ than the other three parameters (see Supplementary Fig. S7).

The importance of increasing Eu/Eu* ${ }_{\text {melt }}$ in driving the change in $\mathrm{Eu} / \mathrm{Eu}^{*}$ at $\sim 60 \mathrm{Ma}$ is consistent with the higher whole-rock Eu/Eu* after $\sim 60 \mathrm{Ma}$ (Fig. 10). Increasing melt $\mathrm{fO}_{2}$ would only affect $\mathrm{Eu} / \mathrm{Eu}^{*}$ zircon and not the evolution of whole-rock $\mathrm{Eu} / \mathrm{Eu}^{*}$, because $f \mathrm{O}_{2}$ changes would not strongly alter the bulk Eu content of the magma. In addition, because whole-rock Eu/Eu* increases in tandem with redox insensitive trace element ratios (e.g., $\mathrm{Sr} / \mathrm{Y}$ ), it is thus best explained by fractionation of amphibole (excludes Eu relative to other REEs) and suppression of plagioclase fractionation (preferentially incorporates Eu relative to other REEs). Therefore, the shift to higher $\mathrm{Eu} / \mathrm{Eu}^{*}{ }_{\text {zircon }}$ at $\sim 60 \mathrm{Ma}$ is interpreted to reflect the composition of magmas that evolved at deeper crustal levels than previously, a signature which zircon inherits upon its crystallisation later in the magma evolution, in the shallow crust.

\section{The decoupling of zircon chemistry from bulk magma compositions}

The ability of $\mathrm{Eu} / \mathrm{Eu}^{*}{ }_{\text {zircon }}$ to record a deep-crustal fractionation history is dependent on it reflecting the bulk magma $\mathrm{Eu} / \mathrm{Eu}^{*}$ (cf., Nathwani et al. 2020). Although Eu/Eu* ${ }_{\text {zircon }}$ appears to reflect changes in the inferred bulk magma $\mathrm{Eu} /$ $\mathrm{Eu}^{*}$ based on the correlation between $\mathrm{Eu} / \mathrm{Eu}^{*}{ }_{\text {zircon }}$ and whole-rock $\mathrm{Eu} / \mathrm{Eu}^{*}$, modification of the melt composition (largely prior crystallisation of plagioclase in the uppercrust) prior to zircon saturation would be expected. The degree of this has implications for the applicability of Eu/ $\mathrm{Eu}_{\text {zircon }}$ as an indicator of long-lived, lower-crustal magma evolution.

Core-rim analyses of zircon provide a means to assess the trajectory and degree of late-stage melt evolution that may overprint the $\mathrm{Eu} / \mathrm{Eu}^{*}$ signature that zircons inherit from the prior magma evolution history. In the early Yarabamba rocks (older than $\sim 60 \mathrm{Ma}$ ), Eu/Eu* ${ }_{\text {zircon }}$ remains low from core to rim (Fig. 9a) which can be explained by $\mathrm{Eu}_{\text {melt }}$ being initially low due to earlier, lower crustal plagioclase fractionation, and remaining low during zircon saturation and growth in the shallow crust (with or without plagioclase crystallisation). The variable core-rim vectors in the Quellaveco Granodiorite zircons (Fig. 9b) could reflect more open-system behaviour of the magma reservoir at this time, wherein periodic recharge of the system would reset Eu/ $\mathrm{Eu}^{*}{ }_{\text {melt }}$ towards the higher $\mathrm{Eu} / \mathrm{Eu}^{*}$ of the magma batches being sourced from the deep crustal reservoir. In between recharge events, cooling of the reservoir and crystallisation of assemblages in which Eu is compatible (i.e., plagioclasedominated) would reduce $\mathrm{Eu} / \mathrm{Eu}^{*}{ }_{\text {melt }}$ and, therefore, also of $\mathrm{Eu} / \mathrm{Eu}^{*}{ }_{\text {zircon}}$. In addition, in situ crystallisation of other accessory phases (titanite and apatite) which preferentially partition Sm and Gd relative to Eu, could have the opposite effect (e.g.,Loader et al. 2017; Rezeau et al. 2019), leading to potentially complex trends. Finally, cycles of magma recharge, cooling and crystallisation could introduce greater melt compositional heterogeneity throughout the upper-crustal magma reservoir (Buret et al. 2016). In the Quellaveco porphyries, similar open-system behaviour is inferred; however, some samples demonstrate more consistently decreasing core-rim Eu/Eu* ${ }_{\text {zircon }}$ values (Fig. 9c) which may represent cooling and crystallisation in the upper crustal magma reservoir between each phase of recharge that triggered fluid saturation and porphyry stock emplacement. The paucity of increasing core-rim $\mathrm{Eu} / \mathrm{Eu}^{*}{ }_{\text {zircon }}$ vectors in the Quellaveco porphyries (Fig. 9c) indicates that the process generating the high $\mathrm{Eu} / \mathrm{Eu}^{*}$ signature occurred prior to zircon saturation. This is consistent with magma evolution at depth producing high Eu/Eu* ${ }_{\text {melt }}$, which zircon inherits upon its late-stage crystallisation in the shallow crust.

Therefore, we conclude that the $\mathrm{Eu} / \mathrm{Eu}^{*}{ }_{\text {zircon }}$ record is a composite of both an early, lower crustal magma history, and a late, shallow crustal melt evolution that is dominated by plagioclase crystallisation. The $\mathrm{Eu} / \mathrm{Eu}^{*}{ }_{\text {zircon }}$ signature of deep crustal evolution will, therefore, be better preserved in earlier-crystallising zircons and/or in the cores of later crystallising zircons (Fig. 8; lower Hf, higher Th/U) that more closely represent the bulk magma composition. Later crystallising zircons, would instead predominantly record the later in-situ melt evolution path during magma storage in 
the upper crust, as seen by the lower Eu/Eu* in such zircons (Fig. 8; higher Hf, lower Th/U). Although this effect does not appear to obscure the early, lower crustal magma history, it adds complexity to the development of Eu/Eu* ${ }_{\text {zircon }}$ as a geobarometer or geohygrometer (e.g., Tang et al. 2020). The integration of $\mathrm{Eu} / \mathrm{Eu}^{*}{ }_{\text {zircon }}$ with indicators of melt differentiation in zircon ( $\mathrm{Hf}$ and $\mathrm{Th} / \mathrm{U})$ in magma suites is, therefore, crucial in distinguishing and characterising early and late magmatic evolution processes.

\section{Conclusions}

Whole-rock and zircon chemistry and geochronology have been used to track the geochemical evolution of a long-lived, upper-crustal arc magma system in the $\sim 12 \mathrm{Myr}$ prior to, and during, the generation of giant porphyry $\mathrm{Cu}-\mathrm{Mo}$ deposits in Southern Peru. Both whole-rock and zircon geochemical data document a distinctive shift in the geochemistry of the Yarabamba intrusive phases, $4 \mathrm{Myr}$ prior to the onset of significant mineralisation in the district. The rocks that represent magmas emplaced after this perturbation are characterised by high $\mathrm{Sr} / \mathrm{Y}, \mathrm{Eu} / \mathrm{Eu}{ }^{*}$ and $\mathrm{La} / \mathrm{Yb}$, which we suggest were generated by increased water content and greater depth of magma evolution in the lower crust that promoted the stability of amphibole ( \pm garnet) and suppressed plagioclase crystallisation. This geochemical change overlaps temporally with a change in the subduction vector of the Nazca plate from oblique to orthogonal and an increase in the rate of convergence, which are interpreted to have increased crustal compression and thickening and which could have impeded magma ascent from deeper levels.

Zircon records an increase in $\mathrm{Eu} / \mathrm{Eu}^{*}$ that occurred at the same time as the increase in $\mathrm{Eu} / \mathrm{Eu} *$ observed in wholerock chemistry. We use mineral-melt partitioning theory to model $\mathrm{Eu} / \mathrm{Eu}^{*}{ }_{\text {zircon }}$ and show that the effect of melt $f \mathrm{O}_{2}$ on $\mathrm{Eu} / \mathrm{Eu}^{*}{ }_{\text {zircon }}$ is subordinate to the effect of zircon crystallisation from a melt with elevated $\mathrm{Eu} / \mathrm{Eu} *$. Therefore, we propose that $\mathrm{Eu} / \mathrm{Eu}^{*}{ }_{\text {zircon }}$ is principally a monitor of $\mathrm{Eu} / \mathrm{Eu}^{*}{ }_{\text {melt }}$ that is predetermined by the lower crustal magma evolution recorded by whole-rock chemistry. Importantly, however, this fingerprint of lower crustal magma evolution in zircon can be partly overprinted by the prior or co-crystallisation of other minerals, predominantly by the onset of significant, upper crustal, plagioclase crystallisation.

Our study confirms previous studies that highlight the importance of high $\mathrm{Sr} / \mathrm{Y}$, high $\mathrm{La} / \mathrm{Yb}$ magma compositions and lower crustal magma evolution in generating worldclass porphyry $\mathrm{Cu}$ deposits (e.g., Richards and Kerrich 2007; Loucks 2014; Chiaradia and Carrichi 2017). Our approach demonstrates the utility of zircon as a tracer of magmatic processes but emphasises that it is necessary to consider its crystallisation relative to other mineral phases in interpreting zircon trace element data for petrogenetic and provenance studies.

Acknowledgements This work was supported by a Science and Solutions for a Changing Planet doctoral studentship funded by the Natural Environment Research Council (grant NE/L002515/1) and Anglo American. We thank David Braxton, Victor Valdivia, Jose Cardenas and Jorge Casaverde at Anglo American for logistical and technical support. We would particularly like to thank Victor Ramos for assistance during the field season in 2019. We thank Tobias Salge for help with scanning electron microscope work and Lauren Tuffield and William Brownscombe for laboratory support. This work benefited from thought provoking discussions with Matthew Loader. We are grateful to associate editor Othmar Müntener, Robert Loucks and an anonymous reviewer for their constructive reviews which greatly improved an earlier version of this manuscript. JW, SL and YB acknowledge funding under Natural Environment Research Council grant (NE/P017452/1) "From arc magmas to ores (FAMOS): A mineral systems approach".

Funding $\mathrm{CN}$ is funded by grant NE/L002515/1. JW, SL and YB acknowledge NE/P017452/1.

Data availability The reported datasets are provided in the electronic supplementary material.

Code availability Code for the $\mathrm{Eu} / \mathrm{Eu}$ * modelling is provided as a Jupyter notebook in PDF format in Supplementary Material 3.

\section{Compliance with ethical standards}

Conflict of interest The authors declare that they have no conflict of interest.

Open Access This article is licensed under a Creative Commons Attribution 4.0 International License, which permits use, sharing, adaptation, distribution and reproduction in any medium or format, as long as you give appropriate credit to the original author(s) and the source, provide a link to the Creative Commons licence, and indicate if changes were made. The images or other third party material in this article are included in the article's Creative Commons licence, unless indicated otherwise in a credit line to the material. If material is not included in the article's Creative Commons licence and your intended use is not permitted by statutory regulation or exceeds the permitted use, you will need to obtain permission directly from the copyright holder. To view a copy of this licence, visit http://creativecommons.org/licenses/by/4.0/.

\section{References}

Aigner-Torres M, Blundy J, Ulmer P, Pettke T (2007) Laser Ablation ICPMS study of trace element partitioning between plagioclase and basaltic melts: An experimental approach. Contrib to Mineral Petrol 153:647-667. https://doi.org/10.1007/s0041 0-006-0168-2

Alonso-Perez R, Müntener O, Ulmer P (2009) Igneous garnet and amphibole fractionation in the roots of island arcs: experimental constraints on andesitic liquids. Contrib to Mineral Petrol 157:541-588. https://doi.org/10.1007/s00410-008-0351-8

Anglo American plc. (2019) Anglo American integrated annual report 2018. https://www.angloamerican.com/investors/annual-repor ting/reports-library/report-2019 
Annen C, Blundy JD, Sparks RSJ (2006) The genesis of intermediate and silicic magmas in deep crustal hot zones. J Petrol 47:505539. https://doi.org/10.1093/petrology/egi084

Arriagada C, Roperch P, Mpodozis C, Cobbold PR (2008) Paleogene building of the Bolivian Orocline: Tectonic restoration of the central Andes in 2-D map view. Tectonics 27:. https://doi. org/https://doi.org/10.1029/2008TC002269

Azadbakht Z, Lentz DR, McFarlane CRM, Whalen JB (2020) Using magmatic biotite chemistry to differentiate barren and mineralized Silurian-Devonian granitoids of New Brunswick, Canada. Contrib to Mineral Petrol 175:. https://doi.org/https://doi. org/10.1007/s00410-020-01703-2

Ballard JR, Palin JM, Campbell IH (2002) Relative oxidation states of magmas inferred from Ce"IV"/Ce"III" in zircon: Application to porphyry copper deposits of northern Chile. Contrib to Mineral Petrol 144:347-364. https://doi.org/10.1007/s00410-002-0402-5

Barreiro BA, Clark AH (1984) Lead isotopic evidence for evolutionary changes in magma-crust interaction, Central Andes, southern Peru. Earth Planet Sci Lett 69:30-42. https://doi. org/10.1016/0012-821X(84)90072-4

Bellido E (1979) Geología del cuadrángulo de Moquegua (hoja: 35-u): Lima. Peru, Inst Geológico Min y Met, p 78

Benavides-Cáceres V (1999) Orogenic evolution of the Peruvian Andes: the Andean Cycle. Geol Ore Depos Cent Andes, Spec Publ Soc Econ Geol 61-107. https://doi.org/https://doi. org/10.5382/SP.07.03

Black LP, Kamo SL, Allen CM et al (2004) Improved 206Pb/238U microprobe geochronology by the monitoring of a trace-element-related matrix effect; SHRIMP, ID-TIMS, ELA-ICP-MS and oxygen isotope documentation for a series of zircon standards. Chem Geol 205:115-140. https://doi.org/10.1016/j.chemg eo.2004.01.003

Blundy J, Wood B (1994) Prediction of crystal-melt partition coefficients from elastic moduli. Nature 372:452-454. https://doi. org/10.1038/372452a0

Boehnke P, Watson EB, Trail D et al (2013) Zircon saturation re-revisited. Chem Geol 351:324-334. https://doi.org/10.1016/j.chemg eo.2013.05.028

Buret Y, von Quadt A, Heinrich C et al (2016) From a long-lived uppercrustal magma chamber to rapid porphyry copper emplacement: Reading the geochemistry of zircon crystals at Bajo de la Alumbrera (NW Argentina). Earth Planet Sci Lett 450:120-131. https ://doi.org/10.1016/j.eps1.2016.06.017

Burnham AD (2020) Key concepts in interpreting the concentrations of the rare earth elements in zircon. Chem Geol 551:. https://doi. org/https://doi.org/10.1016/j.chemgeo.2020.119765

Burnham AD, Berry AJ (2012) An experimental study of trace element partitioning between zircon and melt as a function of oxygen fugacity. Geochim Cosmochim Acta 120:196-212

Burnham AD, Berry AJ, Halse HR et al (2015) The oxidation state of europium in silicate melts as a function of oxygen fugacity, composition and temperature. Chem Geol 411:248-259. https:// doi.org/10.1016/j.chemgeo.2015.07.002

Capitanio FA, Faccenna C, Zlotnik S, Stegman DR (2011) Subduction dynamics and the origin of Andean orogeny and the Bolivian orocline. Nature 480:83-86. https://doi.org/10.1038/nature10596

Carmichael ISE (1991) The redox states of basic and silicic magmas: a reflection of their source regions? Contrib to Mineral Petrol 106:129-141. https://doi.org/10.1007/BF00306429

Chapman JB, Ducea MN, DeCelles PG, Profeta L (2015) Tracking changes in crustal thickness during orogenic evolution with $\mathrm{Sr} / \mathrm{Y}$ : an example from the North American Cordillera. Geology 43:919-922. https://doi.org/10.1130/G36996.1

Chelle-Michou C, Chiaradia M, Ovtcharova M et al (2014) Zircon petrochronology reveals the temporal link between porphyry systems and the magmatic evolution of their hidden plutonic roots (the Eocene Coroccohuayco deposit, Peru). Lithos 198199:129-140. https://doi.org/10.1016/j.lithos.2014.03.017

Chelle-Michou C, Chiaradia M, Béguelin P, Ulianov A (2015) Petrological evolution of the magmatic suite associated with the Coroccohuayco $\mathrm{Cu}(-\mathrm{Au}-\mathrm{Fe})$ porphyry-skarn deposit, Peru. J Petrol 56:1829-1862. https://doi.org/10.1093/petrology/egv056

Chelle-Michou C, Rottier B, Caricchi L, Simpson G (2017) Tempo of magma degassing and the genesis of porphyry copper deposits. Sci Rep 7. https://doi.org/10.1038/srep40566

Chiaradia M, Merino D, Spikings R (2009) Rapid transition to longlived deep crustal magmatic maturation and the formation of giant porphyry-related mineralization (Yanacocha, Peru). Earth Planet Sci Lett 288:505-515. https://doi.org/10.1016/j. epsl.2009.10.012

Chiaradia M (2015) Crustal thickness control on Sr/Y signatures of recent arc magmas: an Earth scale perspective. Sci Rep 5. https ://doi.org/10.1038/srep08115

Chiaradia M, Caricchi L (2017) Stochastic modelling of deep magmatic controls on porphyry copper deposit endowment. Sci Rep 7. https ://doi.org/10.1038/srep44523

Claiborne L, Miller CF, Walker BA et al (2006) Tracking magmatic processes through $\mathrm{Zr} / \mathrm{Hf}$ ratios in rocks and $\mathrm{Hf}$ and $\mathrm{Ti}$ zoning in zircons: an example from the Spirit Mountain batholith, Nevada. Mineral Mag 70:517-543. https://doi.org/10.1180/0026461067 050348

Claiborne LL, Miller CF, Gualda GAR, et al (2017) Zircon as magma monitor: Robust, temperature-dependent partition coefficients from glass and zircon surface and rim measurements from natural systems. In: Microstructural Geochronology: Planetary Records Down to Atom Scale

Clark AH (1990) Geologic and geochronologic constraints on the metallogenic evolution of the Andes of Southeastern Peru. Econ Geol 85:1520-1583. https://doi.org/10.2113/gsecongeo.85.7.1520

Cobbing EJ, Pitcher WS (1972) The Coastal Batholith of central Peru. J Geol Soc London 128:421-454. https://doi.org/10.1144/gsjgs .128.5.0421

Cooke DR, Hollings P, Walshe JL (2005) Giant porphyry deposits: characteristics, distribution, and tectonic controls. Econ Geol 100:801-818. https://doi.org/10.2113/gsecongeo.100.5.801

Demouy S, Paquette JL, de Saint BM et al (2012) Spatial and temporal evolution of Liassic to Paleocene arc activity in southern Peru unraveled by zircon $\mathrm{U}-\mathrm{Pb}$ and $\mathrm{Hf}$ in-situ data on plutonic rocks. Lithos 155:183-200. https://doi.org/10.1016/j.lithos.2012.09.001

DePaolo DJ (1981) Trace element and isotopic effects of combined wallrock assimilation and fractional crystallization. Earth Planet Sci Lett 53:189-202. https://doi.org/10.1016/0012821X(81)90153-9

Dilles JH (1987) Petrology of the Yerington Batholith, Nevada: evidence for evolution of porphyry copper ore fluids. Econ Geol 82:1750-1789. https://doi.org/10.2113/gsecongeo.82.7.1750

Dilles JH, Einaudi MT, Proffett JM Jr, Barton MD (2000) Overview of the Yerington Porphyry Copper District Magmatic to nonmagmatic sources of hydrothermal fluids, their flow paths, alteration affects on rocks, and $\mathrm{Cu}-\mathrm{Mo}-\mathrm{Fe}-\mathrm{Au}$ Ores. Soc Econ Geol Guideb Ser 32(1):55-66

Dilles JH, Kent AJR, Wooden JL et al (2015) Zircon compositional evidence for sulfur-degassing from ore-forming arc magmas. Econ Geol 110:241-251. https://doi.org/10.2113/econgeo.110.1.241

Du J, Audétat A (2020) Early sulfide saturation is not detrimental to porphyry $\mathrm{Cu}-\mathrm{Au}$ formation. Geology 48:519-524. https://doi. org/10.1130/G47169.1

Duffy JA (1993) A review of optical basicity and its applications to oxidic systems. Geochim Cosmochim Acta 57:3961-3970. https ://doi.org/10.1016/0016-7037(93)90346-X 
Ferry JM, Watson EB (2007) New thermodynamic models and revised calibrations for the Ti-in-zircon and $\mathrm{Zr}$-in-rutile thermometers. Contrib Min Petrol 154:429-437. https://doi.org/10.1007/s0041 0-007-0201-0

Fu B, Page FZ, Cavosie AJ et al (2008) Ti-in-zircon thermometry: applications and limitations. Contrib Mineral Petrol 156:197215. https://doi.org/10.1007/s00410-008-0281-5

Green TH, Blundy JD, Adam J, Yaxley GM (2000) SIMS determination of trace element partition coefficients between garnet, clinopyroxene and hydrous basaltic liquids at 2-7.5 GPa and 1080-1200 ${ }^{\circ} \mathrm{C}$. Lithos 53:165-187. https://doi.org/10.1016/ S0024-4937(00)00023-2

Harrison TM, Watson EB (1983) Kinetics of zircon dissolution and zirconium diffusion in granitic melts of variable water content. Contrib Min Petrol 84:66-72. https://doi.org/10.1007/BF01132331

Hildreth W, Moorbath S (1988) Crustal contributions to arc magmatism in the Andes of Central Chile. Contrib Mineral Petrol 98:455489. https://doi.org/10.1007/BF00372365

Horstwood MSA, Košler J, Gehrels G et al (2016) Community-derived standards for LA-ICP-MS U-(Th-)Pb geochronology-uncertainty propagation, age interpretation and data reporting. Geostand Geoanalytical Res 40:311-332. https://doi.org/10.1111/ j.1751-908X.2016.00379.X

Hu J, Liu L, Hermosillo A, Zhou Q (2016) Simulation of late Cenozoic South American flat-slab subduction using geodynamic models with data assimilation. Earth Planet Sci Lett 438:1-13. https:// doi.org/10.1016/j.epsl.2016.01.011

Huber C, Bachmann O, Vigneresse JL, et al (2012) A physical model for metal extraction and transport in shallow magmatic systems. Geochemistry, Geophys Geosystems 13. https://doi. org/10.1029/2012GC004042

Jackson SE, Pearson NJ, Griffin WL, Belousova EA (2004) The application of laser ablation-inductively coupled plasma-mass spectrometry to in situ U-Pb zircon geochronology. Chem Geol 211:47-69. https://doi.org/10.1016/j.chemgeo.2004.06.017

Jaillard E, Soler P (1996) Cretaceous to early Paleogene tectonic evolution of the northern Central Andes $\left(0-18^{\circ} \mathrm{S}\right)$ and its relations to geodynamics. Tectonophysics 259:41-53. https://doi. org/10.1016/0040-1951(95)00107-7

Jenner FE, O'Neill HSC, Arculus RJ, Mavrogenes JA (2010) The magnetite crisis in the evolution of arc-related magmas and the initial concentration of $\mathrm{Au}, \mathrm{Ag}$ and $\mathrm{Cu}$. J Petrol 51:2445-2464. https:// doi.org/10.1093/petrology/egq063

Klaver M, Blundy JD, Vroon PZ (2018) Generation of arc rhyodacites through cumulate-melt reactions in a deep crustal hot zone: evidence from Nisyros volcano. Earth Planet Sci Lett 497:169-180. https://doi.org/10.1016/j.epsl.2018.06.019

Korges M, Weis P, Andersen C (2020) The role of incremental magma chamber growth on ore formation in porphyry copper systems. Earth Planet Sci Lett 552. https://doi.org/10.1016/j. epsl.2020.116584

Lamy-Chappuis B, Heinrich CA, Driesner T, Weis P (2020) Mechanisms and patterns of magmatic fluid transport in cooling hydrous intrusions. Earth Planet Sci Lett 535. https://doi. org/10.1016/j.epsl.2020.11611

Lang JR, Titley SR (1998) Isotopic and geochemical characteristics of Laramide magmatic systems in Arizona and implications for the genesis of porphyry copper deposits. Econ Geol 93:138-170. https://doi.org/10.2113/gsecongeo.93.2.138

Large SJE, Von Quadt A, Wotzlaw JF et al (2018) Magma evolution leading to porphyry $\mathrm{Au}-\mathrm{Cu}$ mineralization at the Ok Tedi deposit, Papua New Guinea: Trace element geochemistry and high-precision geochronology of igneous zircon. Econ Geol 113:39-61. https://doi.org/10.5382/econgeo.2018.4543

Large SJE, Wotzlaw J-F, Guillong M et al (2020) Resolving the timescales of magmatic and hydrothermal processes associated with porphyry deposit formation using zircon $\mathrm{U}-\mathrm{Pb}$ petrochronology. Geochronology 2:209-230. https://doi.org/10.5194/gchro n-2-209-2020

Lee CTA, Leeman WP, Canil D, Li ZXA (2005) Similar V/Sc systematics in MORB and arc basalts: implications for the oxygen fugacities of their mantle source regions. J Petrol 46:2313-2336. https://doi.org/10.1093/petrology/egi056

Lee CTA, Luffi P, Chin EJ et al (2012) Copper systematics in arc magmas and implications for crust-mantle differentiation. Science 336:64-68. https://doi.org/10.1126/science.1217313

Lee RG, Dilles JH, Tosdal RM et al (2017) Magmatic evolution of granodiorite intrusions at the El Salvador porphyry copper deposit, Chile, based on trace element composition and $\mathrm{U} / \mathrm{Pb}$ age of zircons. Econ Geol 112:245-273. https://doi.org/10.2113/ econgeo.112.2.245

Lee RG, Byrne K, D’Angelo M et al (2020) Using zircon trace element composition to assess porphyry copper potential of the Guichon creek batholith and highland valley copper deposit, south-central British Columbia. Miner Depos. https://doi.org/10.1007/s0012 6-020-00961-1

Liang HY, Campbell IH, Allen C, et al (2006) Zircon Ce4+/Ce3+ratios and ages for Yulong ore-bearing porphyries in eastern Tibet. Miner Depos 41. https://doi.org/10.1007/s00126-005-0047-1

Loader MA, Wilkinson JJ, Armstrong RN (2017) The effect of titanite crystallisation on $\mathrm{Eu}$ and $\mathrm{Ce}$ anomalies in zircon and its implications for the assessment of porphyry $\mathrm{Cu}$ deposit fertility. Earth Planet Sci Lett 472:107-119. https://doi.org/10.1016/j. epsl.2017.05.010

Loucks RR (2014) Distinctive composition of copper-ore-forming arcmagmas. Aust J Earth Sci 61:5-16. https://doi.org/10.1080/08120 099.2013.865676

Loucks RR, Fiorentini ML, Rohrlach BD (2018) Divergent T-fO2 paths during crystallisation of $\mathrm{H} 2 \mathrm{O}$-rich and $\mathrm{H} 2 \mathrm{O}$-poor magmas as recorded by $\mathrm{Ce}$ and $\mathrm{U}$ in zircon, with implications for TitaniQ and TitaniZ geothermometry. Contrib to Mineral Petrol 173. https://doi.org/10.1007/s00410-018-1529-3

Luhr JF, Carmichael ISE, Varekamp JC (1984a) The 1982 eruptions of El Chichón Volcano, Chiapas, Mexico: Mineralogy and petrology of the anhydritebearing pumices. J Volcanol Geotherm Res 23:69-108. https://doi.org/10.1016/0377-0273(84)90057-X

Luhr JF, Varekamp JC, Prestegaard KL (1984b) The 1982 eruptions of El Chichón Volcano (Chiapas, Mexico): character of the eruptions, ash-fall deposits, and gasphase. J Volcanol Geotherm Res 23:39-68. https://doi.org/10.1016/0377-0273(84)90056-8

Matjuschkin V, Blundy JD, Brooker RA (2016) The effect of pressure on sulphur speciation in mid- to deep-crustal arc magmas and implications for the formation of porphyry copper deposits. Contrib to Mineral Petrol 171. https://doi.org/10.1007/s0041 0-016-1274-4

Melekhova E, Blundy J, Robertson R, Humphreys MCS (2015) Experimental evidence for polybaric differentiation of primitive arc basalt beneath St. Vincent Lesser Antilles. J Petrol 56:161-192. https://doi.org/10.1093/petrology/egu074

Melekhova E, Blundy J, Martin R et al. (2017) Petrological and experimental evidence for differentiation of water-rich magmas beneath St. Kitts, Lesser Antilles. Contrib to Mineral Petrol 172:. https:// doi.org/10.1007/s00410-017-1416-3

Middlemost EAK (1994) Naming materials in the magma/igneous rock system. Earth Sci Rev 37:215-224. https://doi.org/10.1016/00128252(94)90029-9

Mpodozis C, Cornejo P (2012) Cenozoic tectonics and porphyry copper systems of the chilean andes. In: Society of Economic Geologists, Inc. Special publication, geology and genesis of major copper deposits and districts of the world: a tribute to richard $\mathrm{H}$. Sillitoe, pp 329-360 
Mpodozis C, Ramos VA (1989) The andes of Chile and Argentina. Geol Andes Its Relat to Hydrocarb Miner Resour 11:59-90. https ://doi.org/10.1016/j.aqpro.2013.07.003

Mukasa SB (1986) Zircon U-Pb ages of super-units in the Coastal batholith, Peru: implications for magmatic and tectonic processes. Geol Soc Am Bull 97:241-254. https://doi. org/10.1130/0016-7606(1986)97\%3c241:ZUAOSI\%3e2.0.CO;2

Müntener O, Ulmer P (2018) Arc crust formation and differentiation constrained by experimental petrology. Am J Sci 318:64-89. https://doi.org/10.2475/01.2018.04

Müntener O, Kelemen PB, Grove TL (2001) The role of H2O during crystallization of primitive arc magmas under uppermost mantle conditions and genesis of igneous pyroxenites: An experimental study. Contrib Min Petrol 141:643-658. https://doi.org/10.1007/ s004100100266

Myers JS (1975) Cauldron subsidence and fluidization: mechanisms of intrusion of the coastal batholith of Peru into its own volcanic ejecta. Bull Geol Soc Am 86:1209-1220. https ://doi.org/10.1130/0016-7606(1975)86\%3c1209:CSAFM $\mathrm{O} \% 3 \mathrm{e} 2.0 . \mathrm{CO} ; 2$

Nandedkar RH, Ulmer P, Müntener O (2014) Fractional crystallization of primitive, hydrous arc magmas: an experimental study at 0.7 GPa. Contrib to Mineral Petrol 167:. https://doi.org/10.1007/ s00410-014-1015-5

Nandedkar RH, Hürlimann N, Ulmer P, Müntener O (2016) Amphibole-melt trace element partitioning of fractionating calc-alkaline magmas in the lower crust: an experimental study. Contrib to Mineral Petrol 171:. https://doi.org/https://doi.org/10.1007/ s00410-016-1278-0

Nathwani CL, Loader MA, Wilkinson JJ et al (2020) Multi-stage arc magma evolution recorded by apatite in volcanic rocks. Geology 48:323-327. https://doi.org/10.1130/g46998.1

Newman S, Lowenstern JB (2002) VOLATILECALC: A silicate melt-H2O-CO2 solution model written in Visual Basic for excel. Comput Geosci 28. https://doi.org/10.1016/S0098 -3004(01)00081-4

Noble DC, Sébrier M, Megard F, McKee EH (1985) Demonstration of two pulses of Paleogene deformation in the Andes of Peru. Earth Planet Sci Lett 73:345-349. https://doi.org/10.1016/0012821X(85)90082-2

Pardo-Casas F, Molnar P (1987) Relative motion of the Nazca (Farallon) and South American Plates since Late Cretaceous time. Tectonics 6:233-248. https://doi.org/10.1029/TC006i003p00233

Parmigiani A, Faroughi S, Huber C et al (2016) Bubble accumulation and its role in the evolution of magma reservoirs in the upper crust. Nature 532:492-495. https://doi.org/10.1038/nature17401

Paton C, Hellstrom J, Paul B et al (2011) Iolite: freeware for the visualisation and processing of mass spectrometric data. $\mathrm{J}$ Anal At Spectrom 26:2508-2518. https://doi.org/10.1039/c1ja10172b

Profeta L, Ducea MN, Chapman JB, et al (2015) Quantifying crustal thickness over time in magmatic arcs. Sci Rep 5. https://doi. org/10.1038/srep17786

Ramos VA (2009) Anatomy and global context of the Andes: Main geologic features and the Andean orogenic cycle. In: Backbone of the Americas: Shallow Subduction, Plateau Uplift, and Ridge and Terrane Collision, Memoir of the Geological Society of America. pp 31-65

Reubi O, Blundy J (2009) A dearth of intermediate melts at subduction zone volcanoes and the petrogenesis of arc andesites. Nature 461:1269-1273. https://doi.org/10.1038/nature08510

Rezeau H, Moritz R, Wotzlaw JF et al (2019) Zircon petrochronology of the Meghri-Ordubad pluton, Lesser caucasus: Fingerprinting igneous processes and implications for the exploration of porphyry $\mathrm{Cu}-\mathrm{Mo}$ deposits. Econ Geol 114:1365-1388. https://doi. org/10.5382/econgeo.4671
Richards JP (2011) High Sr/Y arc magmas and porphyry $\mathrm{Cu} \pm \mathrm{Mo} \pm$ Au deposits: just add water. Econ Geol 106:1075-1081. https:// doi.org/10.2113/econgeo.106.7.1075

Richards JP, Kerrich R (2007) Special paper: Adakite-like rocks: their diverse origins and questionable role in metallogenesis. Econ Geol 102:537-576. https://doi.org/10.2113/gsecongeo.102.4.537

Richards JP, Spell T, Rameh E et al (2012) High Sr/Y magmas reflect arc maturity, high magmatic water content, and porphyry $\mathrm{Cu} \pm$ $\mathrm{Mo} \pm$ Au potential: examples from the tethyan arcs of central and eastern iran and Western Pakistan. Econ Geol 107:295-332. https ://doi.org/10.2113/econgeo.107.2.295

Rohrlach B, Loucks R (2005) Multi-million-year cyclic ramp-up of volatiles in a lower crustal magma reservoir trapped below the Tampakan copper-gold deposit by Mio-Pliocene crustal compression in the southern Philippines. Adelaide, PGC Publ. 2:369-407

Rosenbaum G, Giles D, Saxon M et al (2005) Subduction of the Nazca Ridge and the Inca Plateau: insights into the formation of ore deposits in Peru. Earth Planet Sci Lett 239:18-32. https://doi. org/10.1016/j.eps1.2005.08.003

Samperton KM, Schoene B, Cottle JM et al (2015) Magma emplacement, differentiation and cooling in the middle crust: Integrated zircon geochronological-geochemical constraints from the Bergell intrusion, Central Alps. Chem Geol 417:322-340. https ://doi.org/10.1016/j.chemgeo.2015.10.024

Schiller D, Finger F (2019) Application of Ti-in-zircon thermometry to granite studies: problems and possible solutions. Contrib to Mineral Petrol 174. https://doi.org/10.1007/s00410-019-1585-3

Schoene B (2014) U-Th-Pb Geochronology. In: Treatise on geochemistry: Second Edition. pp 341-378

Schoene B, Schaltegger U, Brack P et al (2012) Rates of magma differentiation and emplacement in a ballooning pluton recorded by U-Pb TIMS-TEA, Adamello batholith, Italy. Earth Planet Sci Lett 355-356:162-173. https://doi.org/10.1016/j.epsl.2012.08.019

Seedorff E, Dilles JH, Proffett, John MJ et al (2005) Porphyry deposits: characteristics and origin of hypogene features. Soc Econ Geol One Hundredth Anniv Vol 251-298

Shen P, Hattori K, Pan H et al (2015) Oxidation condition and metal fertility of granitic magmas: Zircon trace-element data from porphyry cu deposits in the central asian orogenic belt. Econ Geol 110:1861-1878. https://doi.org/10.2113/econgeo.110.7.1861

Sillitoe RH (2010) Porphyry copper systems, Sillitoe. Econ Geol 105:3-41. https://doi.org/10.2113/gsecongeo.105.1.3

Sillitoe RH, Mortensen JK (2010) Longevity of Porphyry copper formation at Quellaveco, Peru. Econ Geol 105:1157-1162. https:// doi.org/10.2113/econgeo.105.6.1157

Sillitoe R, Perelló J (2005) Andean copper province: tectonomagmatic settings, deposit types, metallogeny, exploration, and discovery. Econ Geol One Hundredth Anniv Vol 845-890

Simmons AT (2013) Magmatic and hydrothermal stratigraphy of Paleocene and Eocene Porphyry $\mathrm{Cu}-\mathrm{Mo}$ deposits in Southern Peru. Univeristy of British Columbia

Simmons AT, Tosdal RM, Wooden JL et al (2013) Punctuated magmatism associated with porphyry $\mathrm{Cu}-\mathrm{Mo}$ formation in the Paleocene to eocene of southern Peru. Econ Geol 108:625-639. https ://doi.org/10.2113/econgeo.108.4.625

Sisson TW, Grove TL (1993) Experimental investigations of the role of $\mathrm{H} 2 \mathrm{O}$ in calc-alkaline differentiation and subduction zone magmatism. Contrib Min Petrol 113:143-166. https://doi.org/10.1007/ BF00283225

Steinberger I, Hinks D, Driesner T, Heinrich CA (2013) Source plutons driving porphyry copper ore formation: Combining geomagnetic data, thermal constraints, and chemical mass balance to quantify the magma chamber beneath the Bingham Canyon deposit. Econ Geol 108:605-624. https://doi.org/10.2113/econgeo.108.4.605 
Sun S, McDonough W (1995) The composition of the Earth. Chem Geol 120:223-253. https://doi.org/10.1016/0009-2541(94)00140 $-4$

Tang M, Erdman M, Eldridge G, Lee CTA (2018) The redox “filter" beneath magmatic orogens and the formation of continental crust. Sci Adv 4. https://doi.org/10.1126/sciadv.aar4444

Tang M, Ji W-Q, Chu X et al (2020) Reconstructing crustal thickness evolution from europium anomalies in detrital zircons. Geology. https://doi.org/10.1130/g47745.1

Trail D, Bruce Watson E, Tailby ND (2012) Ce and Eu anomalies in zircon as proxies for the oxidation state of magmas. Geochim Cosmochim Acta 97:70-87. https://doi.org/10.1016/j. gca.2012.08.032

Ulmer P, Kaegi R, Müntener O (2018) Experimentally derived intermediate to silica-rich arc magmas by fractional and equilibrium crystallization at 1.0 GPa: an evaluation of phase relationships, compositions, liquid lines of descent and oxygen fugacity. J Petrol 59:11-58. https://doi.org/10.1093/petrology/egy017

Vermeesch P (2018) IsoplotR: a free and open toolbox for geochronology. Geosci Front 9:1479-1493. https://doi.org/10.1016/j. gsf.2018.04.001

Waters LE, Andrews BJ, Lange RA (2015) Rapid crystallization of plagioclase phenocrysts in silicic melts during fluid-saturated ascent: phase equilibrium and decompression experiments. $\mathbf{J}$ Petrol 56:981-1006. https://doi.org/10.1093/petrology/egv025
Wendt I, Carl C (1991) The statistical distribution of the mean squared weighted deviation. Chem Geol Isot Geosci Sect 86:275-285. https://doi.org/10.1016/0168-9622(91)90010-T

Wiedenbeck M, Hanchar JM, Peck WH et al (2004) Further characterisation of the 91500 zircon crystal. Geostand Geoanalytical Res 28:9-39. https://doi.org/10.1111/j.1751-908X.2004.tb01041.x

Wilke M, Behrens H (1999) The dependence of the partitioning of iron and europium between plagioclase and hydrous tonalitic melt on oxygen fugacity. Contrib to Mineral Petrol 137:102-114. https:// doi.org/10.1007/s004100050585

Wilkinson JJ (2013) Triggers for the formation of porphyry ore deposits in magmatic arcs. Nat. Geosci. 6:917-925

Wotzlaw JF, Schaltegger U, Frick DA et al (2013) Tracking the evolution of large-volume silicic magma reservoirs from assembly to supereruption. Geology 41:867-870. https://doi.org/10.1130/ G34366.1

Publisher's Note Springer Nature remains neutral with regard to jurisdictional claims in published maps and institutional affiliations. 